Article

\title{
Simulating Water Resource Availability under Data Scarcity-A Case Study for the Ferghana Valley (Central Asia)
}

\author{
Iuliia Radchenko $^{1, *}$, Lutz Breuer ${ }^{1}$, Irina Forkutsa ${ }^{2}$ and Hans-Georg Frede ${ }^{1}$ \\ 1 Landscape, Water and Biogeochemical Cycles, Research Center for BioSystems, \\ Land Use and Nutrition, Justus Liebig University Giessen, Heinrich-Buff-Ring 26-32, \\ Giessen 35392, Germany; E-Mails: Lutz.Breuer@umwelt.uni-giessen.de (L.B.); \\ Hans-Georg.Frede@umwelt.uni-giessen.de (H.-G.F.) \\ 2 Center for International Development and Environmental Research (ZEU), Justus-Liebig-University \\ Giessen, Senckenbergstr. 3, Giessen 35390, Germany; E-Mail: Irina.Forkutsa@zeu.uni-giessen.de \\ * Author to whom correspondence should be addressed; \\ E-Mail: Iuliia.Radchenko@agrar.uni-giessen.de; Tel.: +49-641-99-37382; Fax: +49-641-99-37389.
}

External Editor: Richard Skeffington

Received: 17 June 2014; in revised form: 29 September 2014 / Accepted: 14 October 2014 / Published: 30 October 2014

\begin{abstract}
Glaciers and snowmelt supply the Naryn and Karadarya rivers, and about $70 \%$ of the water available for the irrigated agriculture in the Ferghana Valley. Nineteen smaller catchments contribute the remaining water mainly from annual precipitation. The latter will gain importance if glaciers retreat as predicted. Hydrological models can visualize such climate change impacts on water resources. However, poor data availability often hampers simulating the contributions of smaller catchments. We tested several data pre-processing methods (gap filling, MODAWEC (MOnthly to DAily WEather Converter), lapse rate) and their effect on the performance of the HBV (Hydrologiska Byråns Vattenavdelning)-light model. Monte Carlo simulations were used to define parameter uncertainties and ensembles of behavioral model runs. Model performances were evaluated by constrained measures of goodness-of-fit criteria (cumulative bias, coefficient of determination, model efficiency coefficients (NSE) for high flow and log-transformed flow). The developed data pre-processing arrangement can utilize data of relatively poor quality (only monthly means or daily data with gaps) but still provide model results with NSE between 0.50 and 0.88 . Some of these may not be accurate enough to directly guide water management applications. However, the pre-processing supports producing key information that may initiate rigging
\end{abstract}


of monitoring facilities, and enable water management to respond to fundamentally changing water availability.

Keywords: hydrological modeling; Monte Carlo simulation; MODAWEC; HBV-light model; lapse rate; multiple linear regression

\section{Introduction}

The Aral-Caspian basin is the major internal drainage area of Central Asia. Its $4,000,000 \mathrm{~km}^{2}$ are $75 \%$ steppe and desert [1]. However, large amounts of water are stored in glaciers, permafrost and snow on high mountain ridges in Kyrgyzstan and Tajikistan in the East of Central Asia. At present, these water storages play the key role in the water management that has to regulate the supply for the livelihood in the Central Asian lowlands including main parts of the Ferghana valley in Uzbekistan (Figure 1, $39.4^{\circ}-42^{\circ} \mathrm{N}, 69.2^{\circ}-73.8^{\circ} \mathrm{E}$ ) [2-5]. The valley floor at about $400 \mathrm{~m}$ is surrounded by the mountain ranges of the Tien Shan and the Alay mountain systems that reach up to $5000 \mathrm{~m}$ a.s.l.: the Chatkal ridge in the north, the Ferghana ridge in the east and the Alay ridge in the south. These orographic conditions protect the valley against the invasion of cold air masses from the north but open it to relatively moist air from the west $[3,6,7]$. Therefore, the Ferghana Valley has relatively warm winters and hot summers [8]. As the moist air from the west is forced to move upwards, which includes adiabatic cooling, the precipitation generally increases with elevation and reaches up to $1300 \mathrm{~mm}$ per year at the northwestern slopes of the Ferghana ridge [8,9].

Figure 1. The Ferghana Valley with FAO (Food and Agriculture Organization) land-use map and delineated upper catchments (in black) using SRTM (Shuttle Radar Topography Mission) DEM (Digital Elevation Model, $90 \mathrm{~m}$ ) and ArcGIS (10) software (Redlands, CA, USA).

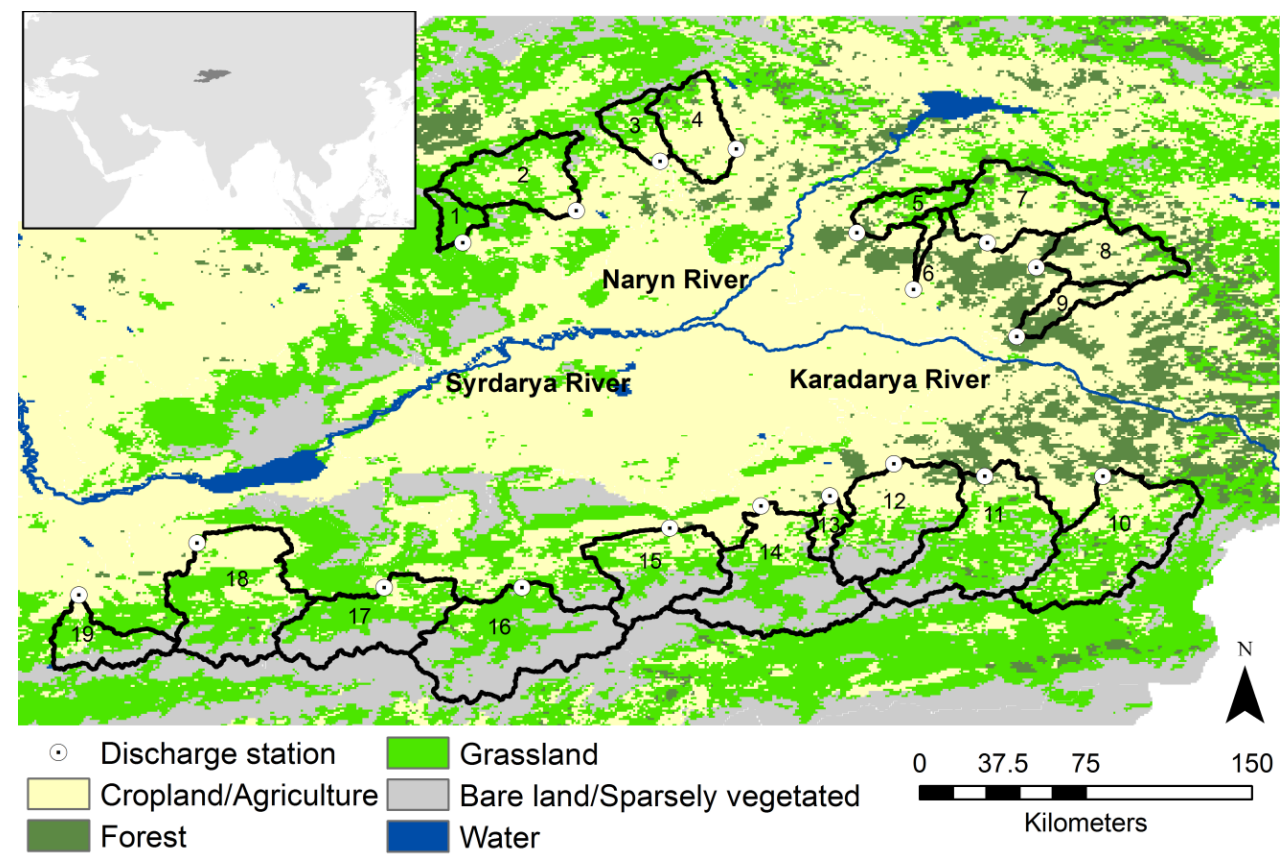


The Karadarya and Naryn rivers have their source in the eastern part of the Ferghana Valley and the Tien Shan mountain system in Kyrgyzstan, from where during summer they are mainly fed by glaciers and snow melt. The confluence of the two rivers in the Uzbek part of the Ferghana Valley forms the Syrdarya River. This river is the main water artery of the valley with a mean discharge of about $39 \mathrm{~km}^{3} \cdot$ year $^{-1}$ [10]. Kyrgyzstan and the three countries Tajikistan, Uzbekistan and Kazakhstan contribute $74 \%$ and $26 \%$ of the water volume of the Syrdarya River, respectively [1]. Smaller streams and catchments at the proximate northern, eastern and southern ridges around Ferghana Valley contribute water mainly from annual rain and snowfall and only a few streams to the south include some glacial melt.

A data compilation of the contributions of the two main and the most relevant smaller rivers shows that (a) the 19 smaller catchments (individually 71-2480 $\mathrm{km}^{2}$ ) cover together an area of around $23,700 \mathrm{~km}^{2}$ or $36 \%$ of the combined headwater areas of the Naryn and Karadarya catchments; and (b) the contribution in discharge to the Syrdarya River is around $7.7 \mathrm{~km}^{3}$ or $\approx 34 \%$ for the 19 catchments $(0.2 \%-6.6 \%$ for single catchments), whereas it is $\approx 13 \%$ for the Karadarya and $53 \%$ for the Naryn River (Table 1, data period 1980-1985).

Based on the analysis of observed climatic data of Central Asia for the 20th century, air temperatures are increasing especially in the lowlands and during winter months [11]. The Intergovernmental Panel on Climate Change (IPCC) predicted a further increase in winter $\left(+2.6{ }^{\circ} \mathrm{C}\right)$ and summer $\left(+3.1{ }^{\circ} \mathrm{C}\right)$ temperatures by 2050 under its lowest future emission scenario B1 [12]. The same study expects precipitation to increase by $+4 \%$ in winter seasons and to decrease by $-2 \%$ to $-4 \%$ in spring and summer seasons.

The total area covered by glaciers in Kyrgyzstan decreased from $8076 \mathrm{~km}^{2}$ in 1960 to $7400 \mathrm{~km}^{2}$ at around 1980 and further to $6500 \mathrm{~km}^{2}$ in 2000 [13]. This corresponds to a $20 \%$ glacier recession for the period 1960-2000. The Tien Shan glaciers alone showed a reduction of $14.2 \%$ between 1943 and 2003 [4]. According to [14] glacier recession for the period 1970-2000 varied from $9 \%$ to $19 \%$ in different regions of the Tien Shan. Finally, many authors assume that the rate of glacial melt in Central Asia has accelerated since the 1970s $[4,15,16]$.

According to [17], the future changes in precipitation, glacial melt, groundwater extraction, reservoir construction, and population growth will involve only a moderate risk of water shortage in the Syrdarya River basin. In contrast, the IPCC emphasized with very high confidence that Central Asia is under high water stress, and that water resources are extremely vulnerable to climate change [12]. Accordingly, the further decrease of glaciers will most likely lead to runoff changes from the Naryn and Karadarya rivers. The volume of water discharged into the major rivers of the region may increase in the short-term but decrease over the long-term. With respect to climate change scenarios, a reduction in discharge by $6 \%-10 \%$ in the Syrdarya River basin is projected by 2050 [1]. Thus, the contributions of small, mainly precipitation-driven catchments may become more important for the water balance of the Ferghana Valley in coming decades. As the people in the region depend on irrigated agriculture, it is of significant interest to assess the contribution of the small upper-catchments under current conditions, and to simulate the future runoff dynamics [18,19]. 
Table 1. Comparison of discharge data $\left(\mathrm{km}^{3} \cdot \mathrm{year}^{-1}\right)$ of the 19 upper sub-catchments flowing into the Syrdarya in relation to the inflows from the Naryn and Karadarya rivers (Data compiled from [20], obtained from the Central-Asian Institute of Applied Geosciences (CAIAG), Kyrgyz-Russian Slavic University (KRSU), and the Global Runoff Data Center (GRDC)* [21], retrieved 19.04.2011, (D)—data with gaps).

\begin{tabular}{|c|c|c|c|c|c|c|c|}
\hline \multirow{2}{*}{$\begin{array}{l}\text { Catchment } \\
\text { Name } \\
\end{array}$} & \multirow{2}{*}{$\begin{array}{c}\text { Area } \\
\left(\mathbf{k m}^{2}\right) \\
\end{array}$} & \multirow{2}{*}{$\begin{array}{c}\begin{array}{c}\text { Elevation } \\
\text { (Gauge Station) }\end{array} \\
\text { (m a.s.l.) }\end{array}$} & \multirow{2}{*}{$\begin{array}{c}\text { Discharge } \\
\left(\mathrm{km}^{3} \cdot \mathrm{year}^{-1}\right) \\
\end{array}$} & \multirow{2}{*}{$\begin{array}{c}\begin{array}{c}\text { Contribution } \\
\text { to Total Discharge }\end{array} \\
(\%) \\
\end{array}$} & \multicolumn{3}{|c|}{$\begin{array}{c}\text { Temporal Resolution of Data } \\
(\text { Daily }=\text { D, Monthly }=\text { M) }\end{array}$} \\
\hline & & & & & Precipitation & Temperature & Discharge \\
\hline 1 Gavasay & 361 & 1716 & 0.13 & 0.6 & $\mathrm{D}$ & M & D (1980-1985) \\
\hline 2 Kassansay & 1130 & 1350 & 0.19 & 0.9 & $\mathrm{D}$ & M & D (1980-1985) \\
\hline 3 Padshaata & 366 & 1536 & 0.15 & 0.7 & $\mathrm{D}$ & M & D (1980-1985) \\
\hline 4 Aflatun & 863 & 2000 & 0.29 & 1.4 & $\mathrm{D}$ & M & D (1980-1985) \\
\hline 5 Maylisuu & 530 & 985 & 0.26 & 1.3 & $\mathrm{D}$ & M & D (1980-1985) \\
\hline 6 Shidansay & 126 & 1016 & 0.05 & 0.2 & $\mathrm{D}$ & M & D (1980-1985) \\
\hline 7 Tentyaksay & 1300 & 1023 & 0.83 & 4.1 & $\mathrm{D}$ & M & D (1980-1985) \\
\hline 8 Kugart & 1010 & 1168 & 0.54 & 2.7 & D & D & D (1980-1985) \\
\hline 9 Changet & 381 & 813 & 0.06 & 0.3 & $\mathrm{D}$ & $\mathrm{M}$ & $\mathrm{D}(1980-1983,1985)$ \\
\hline 10 Kurshab & 2010 & 1543 & 0.55 & 2.7 & $\mathbf{D}$ & (D) & D (1980-1985) \\
\hline 11 Akbura & 2260 & 1327 & 0.62 & 3.0 & D & (D) & D (1980-1985) \\
\hline 12Aravansay & 1680 & 1068 & 0.22 & 1.1 & $\mathrm{D}$ & $\mathrm{M}$ & D (1980-1985) \\
\hline 13 Abshirsay & 230 & 1500 & 0.05 & 0.2 & $\mathrm{D}$ & M & D (1980-1985) \\
\hline 14 Isfiramsay * & 2220 & 1017 & 0.59 & 2.9 & $\mathrm{D}$ & $\mathrm{M}$ & $\mathrm{D}(1980-1985)$ \\
\hline 15 Shakimardan & 1180 & 1065 & 0.25 & 1.2 & $\mathbf{D}$ & (D) & D (1980-1985) \\
\hline 16 Sokh * & 2480 & 1140 & 1.35 & 6.6 & $\mathrm{D}$ & $\mathrm{M}$ & D (1980-1985) \\
\hline 17 Isfara & 1560 & 1283 & 0.43 & 2.1 & $\mathrm{D}$ & (D) & D (1980) \\
\hline 18 Khodjabakirgan & 1740 & 1730 & 0.29 & 1.4 & $\mathrm{D}$ & M & D (1980-1983) \\
\hline $19 \mathrm{Aksu}$ & 712 & 1100 & 0.11 & 0.5 & $\mathrm{D}$ & $\mathrm{M}$ & $\mathrm{D}(1980-1983)$ \\
\hline \multicolumn{4}{|c|}{ Major rivers } & $\sim 34$ & & & \\
\hline Naryn * & 58,400 & 498 & 10.7 & $\sim 53$ & & & \\
\hline Karadarya $*$ & 7402 & 890 & 2.68 & $\sim 13$ & & & \\
\hline
\end{tabular}


About 12 million people live in the Ferghana valley [22], and most of the local families as well as many other people in Central Asia depend on the agricultural production of this specific area. Thus, for many water-users in the Ferghana Valley and beyond, information about future water availability is of utmost importance. Therefore, model projections are urgently needed that capture the impact of changes in precipitation patterns on annual flows with sufficient accuracy to support reservoir management and water resource planning. However, available meteorological and hydrological data for the aforementioned 19 catchments are limited (Table 1). For example, although temperature is important for estimating evapotranspiration and thereinafter for closing the water balance in semi-arid regions [23,24], daily temperature data sets for several years are at hand only for five weather stations. Only monthly temperature data exist for the rest of the stations (Figure 2). Accordingly, the term "data scarcity" in this study refers to insufficient climate network coverage across the Ferghana Valley, especially regarding temperature data where the density of stations is less than 1 per $5000 \mathrm{~km}^{2}[25,26]$.

Figure 2. The Ferghana Valley with available meteorological data and four studied catchments (in green).

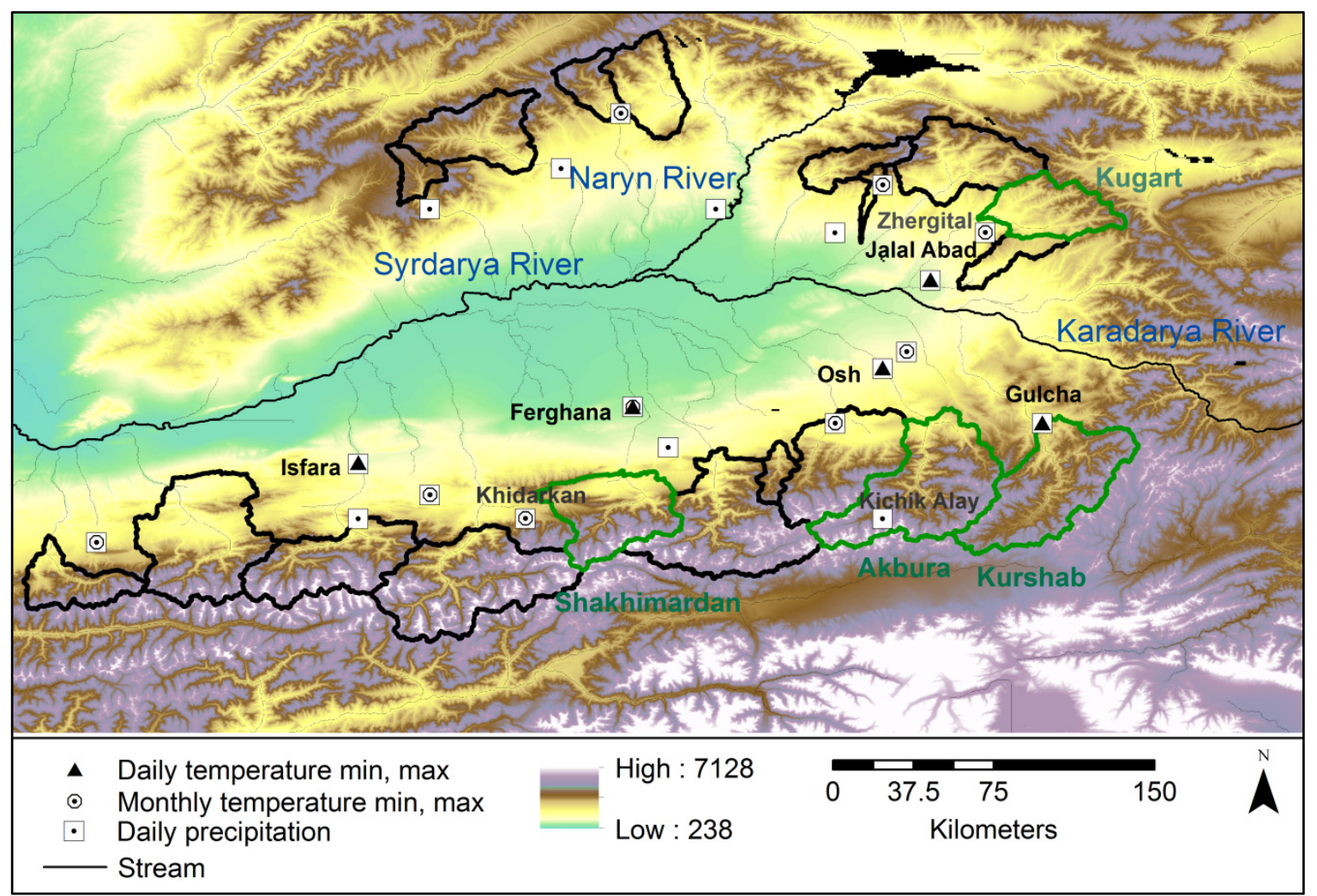

Widespread data scarcity cannot be gap-filled in a way that the output enables local water managements to rely on the synthesized data for the decisions in water allocation to users. Thus, results from synthesizing regional scale data with larger gaps may not be overstated. However, even rough estimations on the potential direction of change are highly appreciated by stakeholders and decision-makers, because water resources are so vulnerable in this area of the world. Hence, the scope of the present work was to develop an approach that can facilitate hydrological modeling of water resource availability under current climatic conditions based on a number of limited data sets (Figure 3). 
Our straightforward approach to hydrological modeling agrees well with suggestions by [27,28] and takes into account a number of performance criteria (Nash-Sutcliffe efficiency for high and log-transformed flow, and difference in annual water balance), and provides a meaningful representation of hydrological processes, the transformation of behavioral parameter sets in time (validation), and a sensitivity analysis of the model's parameters. We selected the four river catchments with the most complete data and tested hydrological model performance given these aspects. Moreover, we tested MODAWEC weather generator for its applicability in the study region. MODAWEC converts monthly temperature data into daily values since only several weather stations are available at daily resolution (Figure 2). To decide whether or not MODAWEC can be used for research on the other 15 catchments of the valley, the results of simulated hydrological outputs were compared, in terms of results from the two databases representing either generated or measured temperature (Figure 3).

Figure 3. Schematic representation of the selected model approach.

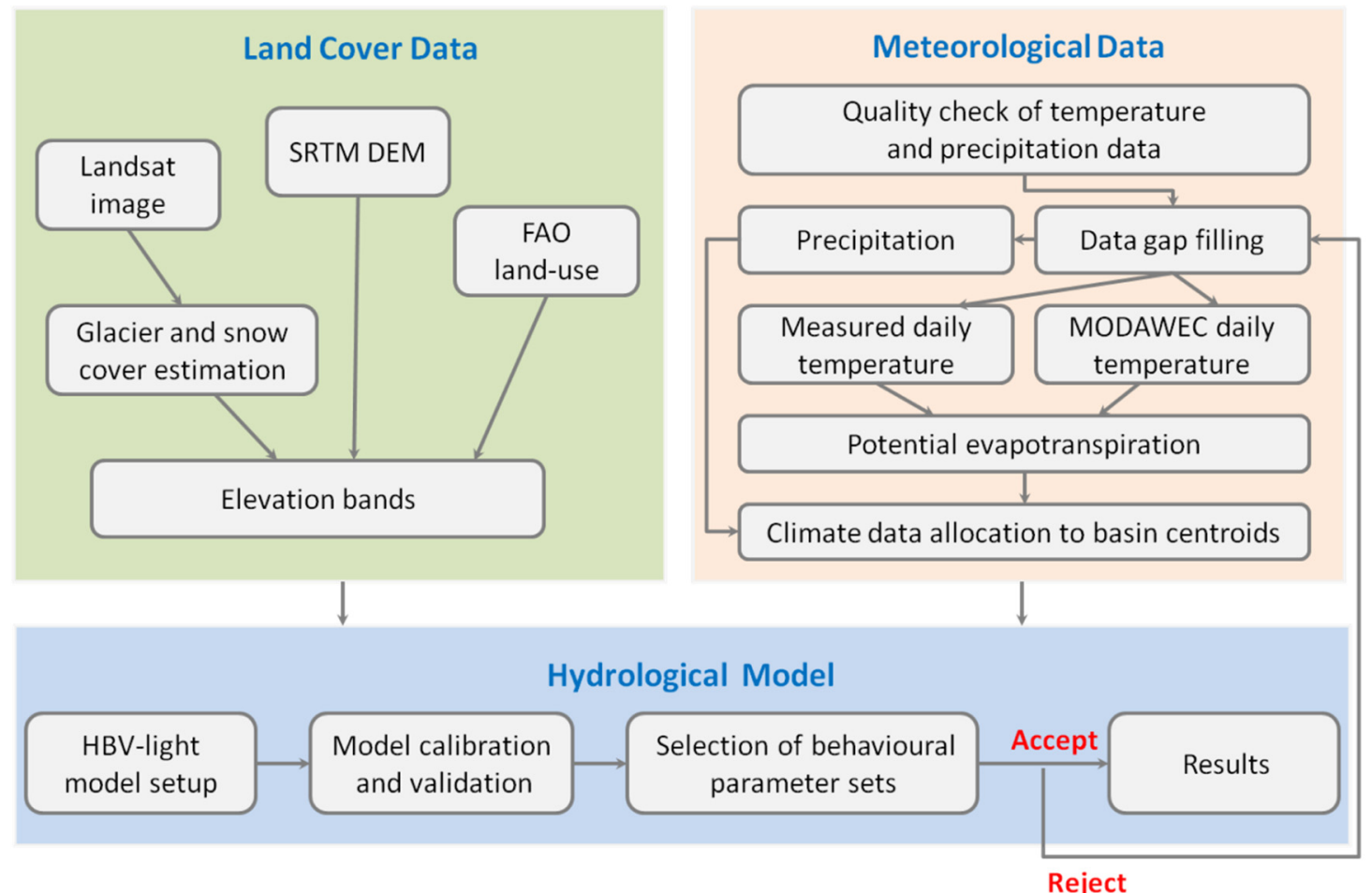

Preference was given to a lumped hydrological model for the hydrological simulation because of the limited quality of forcing data, i.e., referring to the completeness of observed daily meteorological data for the study period. Amongst others, models from the HBV (Hydrologiska Byråns Vattenavdelning) family have proven to provide reliable results for mountainous catchments of Central, East and South Asia, and have recently been used for climate change impact studies in the region [29-35]. We used the recently upgraded version of the HBV-light model for the water balance investigation of the Ferghana Valley, because this version is capable of simulating glacial melt [36,37]. We used a Monte Carlo approach to investigate the effect of model parameter uncertainty [38,39], which is only one part of the global model uncertainty that can arise from errors in input data, the model parameters, or the model structure [38,40-42]. In addition, the influence of the input parameters on the model's output was assessed using sensitivity analysis $[43,44]$. 


\section{Materials and Methods}

\subsection{Study Area}

The four pilot watersheds with the most comprehensive data sets are the Kugart River, the Akbura River, the Kurshab River and the Shakhimardan River basins. A complete record of daily air temperature was available only for one weather station (Jalal Abad) provided by the NCDC (National Climatic Data Center), while for four other stations (Osh, Gulcha, Ferghana, Isfara) there are temporal gaps in the database (Figure 2). The average monthly temperature for the period 1980-1985 at lower elevations (Ferghana, El. $577 \mathrm{~m}$ a.s.1.) varies from $-0.4{ }^{\circ} \mathrm{C}$ in January to $28.9^{\circ} \mathrm{C}$ in July. At medium elevations (Gulcha, El. $1542 \mathrm{~m}$ a.s.1.) temperatures range from -4.5 to $20.3^{\circ} \mathrm{C}$ and decreases to between -8.3 to $15.8{ }^{\circ} \mathrm{C}$ at high elevations (Kichik Alay, El. $2360 \mathrm{~m}$ a.s.1.) (Figure 2). The patterns of monthly mean temperature are similar for the four studied catchments, with warm periods starting in April-May and ending in September-October (Figure 4). Likewise, annual precipitation patterns are comparable between locations with maximum precipitation occurring during April-May and a secondary peak in October-November (Figure 4).

Figure 4. Hydrometeorological regime for the four studied catchments for the period 1980-1985 (constructed based on the available database).

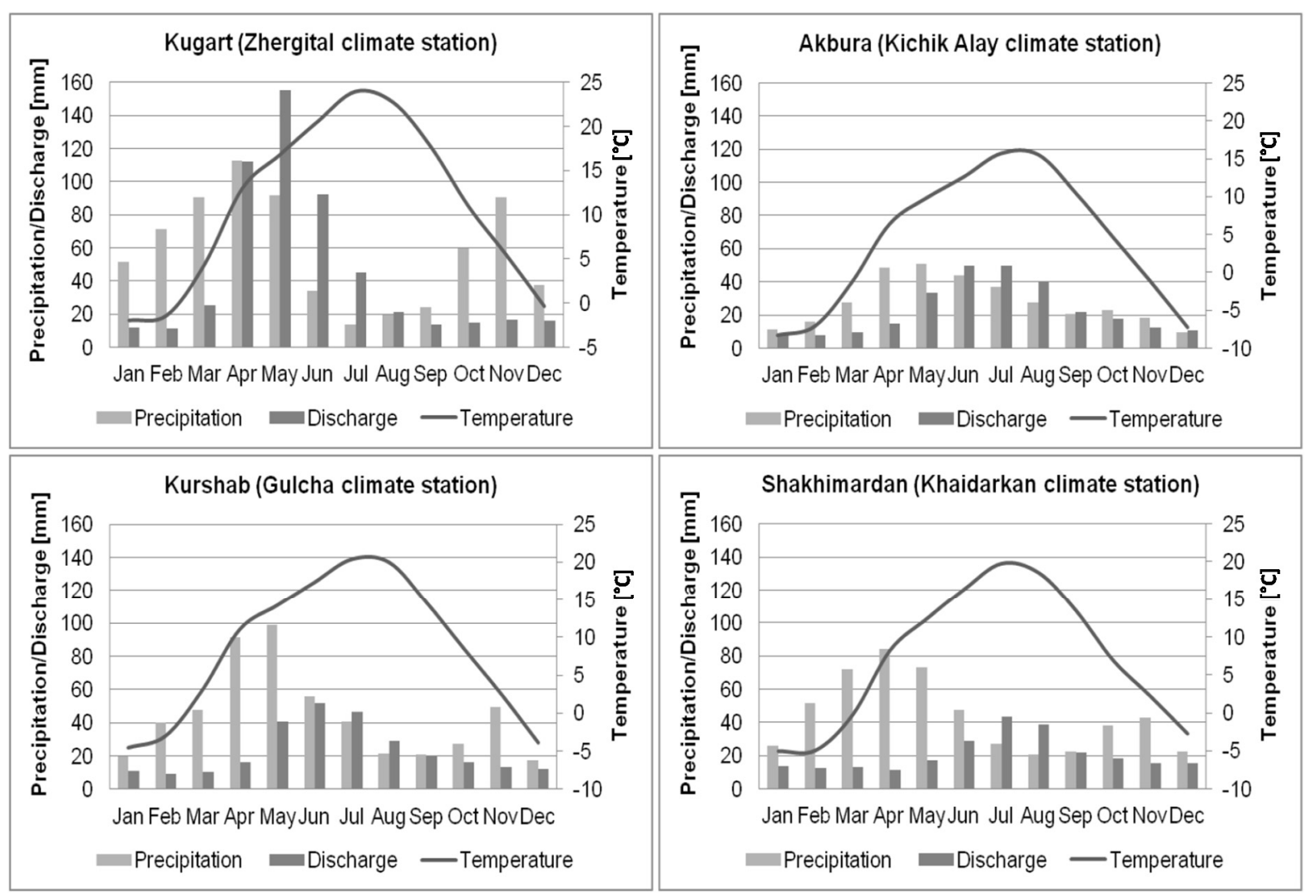

Hydrometeorological and land-use characteristics of the studied catchments are presented in Table 2. The annual discharge varies from 274 (Akbura) to $537 \mathrm{~mm}$ (Kugart) for the studied period with rainfall/runoff ratios of 0.48 (Shakhimardan) to 0.86 (Akbura). The Kugart River basin is mainly precipitation and snowmelt fed, while the other three studied basins are primarily snow and glacial-melt fed. 
Table 2. Hydrometeorological and land-use characteristics of the four studied catchments.

\begin{tabular}{ccccc}
\hline River Catchments & Kugart & Akbura & Kurshab & Shakhimardan \\
\hline Annual discharge, mm & 537 & 274 & 277 & 251 \\
Annual precipitation, mm & 710 & 319 & 530 & 527 \\
Average annual temperature, ${ }^{\circ} \mathrm{C}$ & 11.0 & 4.2 & 8.3 & 7.0 \\
Forest, \% & 21.0 & 2.5 & 14.0 & 0.1 \\
Grassland/Cropland, \% & 79.0 & 52.0 & 58.0 & 65.4 \\
Sparsely vegetated/Bare lands, \% & - & 45.5 & 28.0 & 34.4 \\
\hline
\end{tabular}

The dominant vegetation zones were classified based on FAO land-use/land-cover data [45]. Forests cover up to $21 \%$ (Kugart), while the largest portions of the catchments are made up of grassland/cropland (52\%-79\%) and sparsely vegetated and bare lands. Based on the World Reference Base for soil resources [46], the prevalent soils in the research area are Leptosols, Cambisols and Fluvisols, whereby the first and the latter two correspond roughly to sparsely vegetated/bare lands and grassland/cropland, respectively. In addition, the river terraces along the studied catchments are often used for agriculture, producing cotton, cereals, grapes, sugar beets, fruits and nuts.

Information about the distribution of glacial and snowfield areas in different elevation ranges is presented in Table 3. Glacier and permanent snow cover are illustrated in Figure 5.

Table 3. Distribution of the glacier and permanent snow covered area at different elevations in the Akbura, Kurshab and Shakhimardan river basins (Kugart river basin is non-glaciated).

\begin{tabular}{|c|c|c|c|c|c|c|}
\hline \multirow{2}{*}{$\begin{array}{c}\text { Elevation Zone } \\
\text { (m a.s.l.) } \\
\end{array}$} & \multicolumn{2}{|c|}{ Akbura Basin Coverage, 1975} & \multicolumn{2}{|c|}{ Kurshab Basin Coverage, 1972} & \multicolumn{2}{|c|}{ Shakhimardan Basin Coverage, 1978} \\
\hline & $\left(\mathrm{km}^{2}\right)$ & $(\%)$ & $\left(\mathrm{km}^{2}\right)$ & $(\%)$ & $\left(\mathrm{km}^{2}\right)$ & $(\%)$ \\
\hline $5000-5500$ & - & - & - & - & 0.6 & 0.05 \\
\hline $4500-5000$ & 46.5 & 2.06 & 0.2 & 0.01 & 8.4 & 0.71 \\
\hline $4000-4500$ & 124.5 & 5.51 & 33.7 & 1.68 & 18.7 & 1.58 \\
\hline $3500-4000$ & 16.9 & 0.75 & 43.2 & 2.15 & 6.8 & 0.58 \\
\hline $3000-3500$ & 0.5 & 0.02 & 3.1 & 0.15 & 0.2 & 0.02 \\
\hline $2500-3000$ & 1.8 & 0.08 & - & - & - & - \\
\hline $2000-2500$ & 1.4 & 0.06 & - & - & - & - \\
\hline Sum & 191.6 & 8.48 & 80.2 & 3.99 & 34.7 & 2.94 \\
\hline
\end{tabular}

Figure 5. The Landsat MSS (Multispectral Scanner System) satellite images (79 m) with delineated glacial and snowfield area.
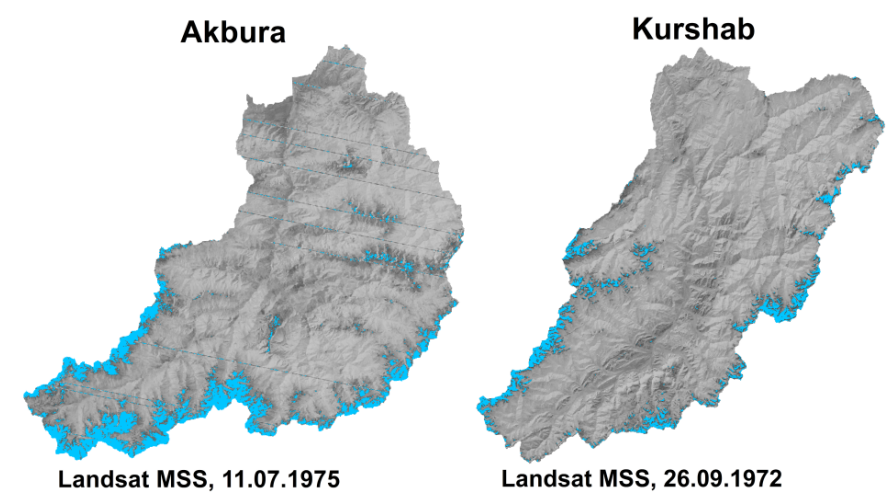

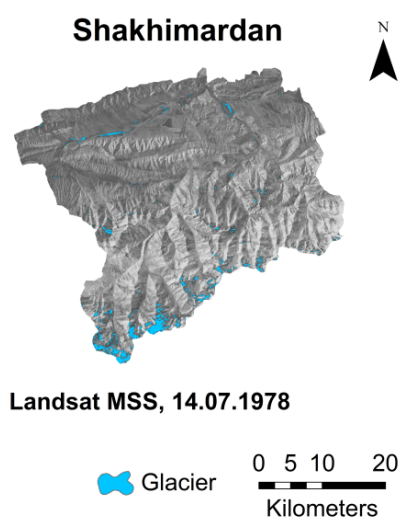


For the Akbura River basin the glacial and snowfield area is $8.5 \%\left(192 \mathrm{~km}^{2}\right)$, in the Shakhimardan watershed the glacial and permanent snow cover extends over $\approx 3 \%\left(\approx 35 \mathrm{~km}^{2}\right)$ and for Kurshab over $\approx 4 \%\left(80 \mathrm{~km}^{2}\right)$ of the catchment's area.

\subsection{Glacial and Snowfield Area}

As the HBV-light model requires more detailed information on vegetation and glacial coverage for different elevation ranges within a catchment, the area of glacier and snowfield was derived from Landsat 1-3 MSS satellite images for the Akbura (1975), Kurshab (1972) and Shakhimardan (1978) (Figure 5). The geo-referenced satellite images were obtained from the United States Geological Survey (USGS). The images were chosen based on their availability in the archive and cloud cover criteria. Snow and glaciers are represented in white color in visible bands due to high reflectivity [47]. Different methods for glacial and snow cover mapping exist, e.g., visual, normalized difference snow index, supervised and unsupervised classification. We distinguished the snow covered area based on satellite images using the spectral reflectance characteristics of snow. Hence, a threshold method was implemented using the brightness values (0-255) in properties of the images. The glacial and permanent snow cover areas were reclassified in ArcGIS (10) based on the different thresholds (as natural break) for the three images due to quality differences in the images. Instead of ground truth data we used soft information from published data on glacier extent close to the period when images were taken [48]. Additionally, glacier and snowfield borders were defined by visual interpretation using scanned, published physical maps from archives. Finally, elevation zone maps of the Akbura, Kurshab and Shakhimardan river basins were derived from DEM and overlapped with glacial and snowfield cover maps to calculate the areas on each elevation zone (Figure 5).

\subsection{Data Gap Filling}

A major problem for many Central Asian study regions is data limitation. The best data coverage available for the catchments is for 1980-1985 (Table 1), but even these time series have gaps of many days in the temperature records and for April, 1985 in the precipitation records. Gap filling details relative to the two parameters are explained hereinafter.

\subsubsection{Temperature}

A linear regression method was used in order to bridge the gaps in the temperature records [49-51]. The best data set within the study area refers to the Jalal Abad climate station, which has only small gaps $(0.5 \%)$ in the temperature records. Here we used a within-station method based on the averaging of previous and following days of the temperatures. The daily temperature data for the Ferghana climate station contains $0.3 \%-4.4 \%$ gaps, which were filled using the within-station and linear interpolation methods. The temperature records for the Osh climate station cover $64 \%-92 \%$ of a year, and this is respectively $9 \%-61 \%$ for the Gulcha climate station. The monthly correlation coefficients of the temperature data between the Jalal Abad and Osh climate stations span from 0.70 to 0.97 , and between the Gulcha and Osh climate stations the coefficients range from 0.60 to 0.92 . 
Temperature data of each station were allocated to the centroids (i.e., mean elevation) of the four respective basins (Figure 2) considering monthly temperature lapse rates [52-54]. Allocation to the centroids worked well, as they represent the mean elevations in the catchments. The HBV-light model further corrects temperature and precipitation at different elevation zones using lapse rates based on the reference elevation [55]]. Since the model uses an annual lapse rate, we calculated monthly ones to allocate and correct temperature. The monthly lapse rates were estimated based on the available annual average temperature data (1980-1985) from 17 climate stations in the Ferghana Valley (Figure 2), ranging in elevation from 577 to $2360 \mathrm{~m}$ a.s.1. The temperature lapse rates vary from $0.34{ }^{\circ} \mathrm{C} / 100 \mathrm{~m}$ (December) to $0.82{ }^{\circ} \mathrm{C} / 100 \mathrm{~m}$ (June), and the average lapse rate is $0.58{ }^{\circ} \mathrm{C} / 100 \mathrm{~m}$.

\subsubsection{Precipitation}

Within the study area five weather stations with complete precipitation time series (except for April 1985) are available for the period 1980-1985. These climate stations were tested for correlation with the other 15 stations to select the most suitable weather station based on the highest correlation coefficient (0.45-0.96) in order to fill the gaps for April 1985 using the linear regression method.

Similar to the temperature data, precipitation data were also corrected for altitude when allocating to the centroids. A stepwise multiple linear regression (MLR) method [56-60] using R 2.15 [57] was used considering annual data from 20 precipitation gauges (ranging in elevation from 826 to $1551 \mathrm{~m}$ a.s.1., 1980-1985, Figure 2), including information on altitude, latitude and longitude. The resulting equation was $p(\mathrm{~mm})=-8531+211.2$ Lat +0.219 Alt, with $r=0.70$. For quality control, we checked correlation coefficients between measured precipitation at neighboring weather stations and generated precipitation for the centroids $(r=0.65-0.84 ; p \leq 0.05)$.

\subsection{Weather Generator}

Weather generators produce data that can be used as inputs for hydrological models [61-63]. MODAWEC was chosen for the required input data (mean monthly precipitation, mean monthly maximum and minimum temperature, and number of wet days) corresponding to the data available for the study area. According to [64,65], precipitation is considered as an independent variable and it is calculated using a first-order Markov chain approach. The Markov chain model describes the occurrence of precipitation based on the probability that a dry day is followed by a wet day and a wet day occurs after previous wet days $[64,65]$. The amount of precipitation is calculated using a modified exponential distribution considering the status (wet or dry) of the previous day $[64,65]$. Temperature is dependent on precipitation insofar that during rainy days the temperature is usually lower than in dry days. Therefore, the daily temperature was generated based on correlations with rainfall events [65]. MODAWEC-derived data were tested for their applicability in replacing measured daily temperature in running the HBV-light model.

\subsection{The HBV-Light Model, Calibration and Validation}

The conceptual, lumped HBV-light model [37,55] simulates daily discharge using daily precipitation, temperature and potential evapotranspiration (PET) as input data. In depth details and descriptions on 
the model are available [37,66-68]. Briefly, the model includes four different routines: snow, soil, groundwater and routing. The snow routine is based on a degree-day method, where precipitation is considered to be rain or snow with respect to a threshold temperature, TT $\left({ }^{\circ} \mathrm{C}\right)[37,67,69]$. The soil routine simulations depend on actual evaporation and water storage properties $[69,70]$. The groundwater routine is governed by percolation rate (PERC) and recession coefficients (K1, K2) [37,70]. Finally, the runoff generation is characterized by the shape of a triangular weighting function $[67,69]$.

This study used the most recent version of the HBV-light model, which differs from the previous versions by being able to reflect glacial melt [36]. The glacial melt is calculated after snowpack disappearance using a degree-day factor method and depending on slope and exposition [36,37]. In our set-up we separated catchments into 500 m elevation zones, resulting in 6, 8, 7 and 9 zones for Kugart (elevation range 1118-3717 m a.s.1.), Akbura (1395 to $4977 \mathrm{~m}$ a.s.1.), Kurshab (1562 to $4623 \mathrm{~m}$ a.s.1.), and Shakhimardan (1213 to $5316 \mathrm{~m}$ a.s.1.), respectively.

The HBV-light model considers temperature and precipitation changes with elevation. We used the

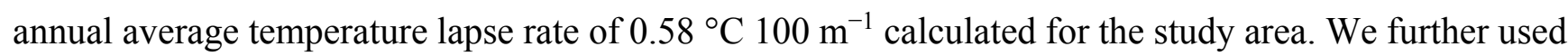
a straightforward $10 \%$ increase in precipitation for every $100 \mathrm{~m}$ increase in elevation as suggested by [55]. A more complex MLR for precipitation, which considers the elevation and latitude as described above, is not readily compatible to HBV-light inputs. Reference evapotranspiration was calculated based on the FAO Penman-Monteith approach [71,72] using the CROPWAT 8.0 model [73]. The CROPWAT model requires input data on elevation, latitude, longitude, and daily means of maximum and minimum temperature [73]. It further requires a crop coefficient for calculation of PET [71]. In this study, the crop coefficient was averaged for the different vegetation types in the region.

HBV-light is a conceptual model and its parameters are not physically-based. We used a lumped model set up with up to nine elevation bands and three vegetation zones, but no additional sub-catchments or spatially variable model parameters due to missing hydrological data. Apart from a manual calibration, the model allows for a Monte Carlo (MC)-based random allocation of parameters from pre-defined parameter ranges. According to the equifinality concept, there is no optimal parameter set but several behavioral sets $[41,74,75]$. This concept best matches the uncertainty of the model set-up that is characterized by relatively poor quality forcing data. We thus used the MC-based parameter estimation technique. The available time series was split into calibration (1980-1983) and validation (1984-1985) periods. Initially, the model was run 10,000 times with broader parameter ranges to identify suitable parameter bounds for each catchment. Afterwards, 500,000 model runs within these parameter bounds were used to derive behavioral parameter sets for 12 (Kugart; excluding glacial melt parameters) and 14 (Akbura, Kurshab, Shakhimardan) parameters considering both measured and MODAWEC-generated daily temperature data.

The parameter sets were treated as being behavioral in calibration and validation periods according to three goodness-of-fit criteria: (1) The Nash Sutcliff efficiency (NSE) which needs to be $\geq 0.50$ to consider the model efficient in matching dominant runoff events; (2) The Nash-Sutcliffe efficiency of log-transformed flow (NSElog) $\geq 0.50$ was used to assess the model's capability in simulating recession flow periods; (3) The cumulative mean difference between observed and simulated runoff predictions for the entire simulation period shall not be outside the range of $0 \pm 20 \mathrm{~mm}$ as a measure of the model's suitability for simulating overall available water resources (e.g., for agricultural production). The same objective functions have been applied in other studies [76-80]. In addition, NSE results were 
crosschecked using the coefficient of determination $\left(R^{2}\right)$. Three months were selected as a model warm-up period so that evaluated simulation starts in April 1980. During the validation the year 1983 was used for warm-up.

\section{Results and Discussion}

MODAWEC was tested using the database of the four studied catchments for its applicability in the region as the converter from monthly into daily temperatures. Results reveal that measured and generated mean maximum, minimum and average temperature data for corresponding weather stations (Figure 2) are highly correlated ( 0.80 to 0.91$)$. Figure 6 shows generated and measured average temperature values at the four corresponding weather stations of the studied basins. Thus, the generator is capable of representing the main features and fluctuations that are similar to the observed temperatures.

Figure 6. Time series plots of generated and measured temperature at the corresponding weather stations (WS) of the four studied river catchments.
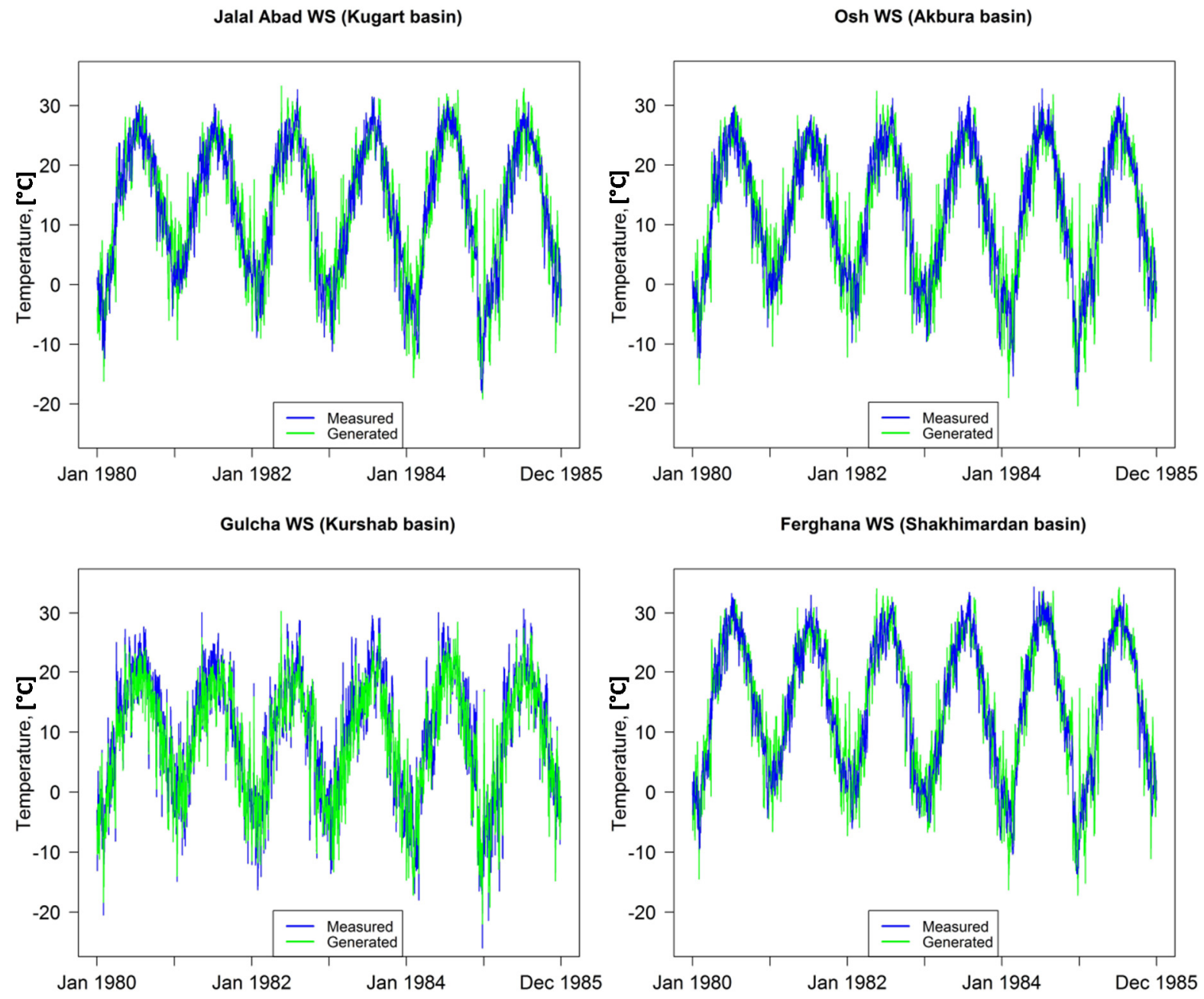

The corrected precipitation for the mean elevations of the studied catchments using MLR method and measured precipitation at the neighbor stations (Figure 2) are presented in Figure 7. The correlation coefficients vary from 0.65 in the Kugart river basin to 0.84 in the Shakhimardan river basin. It can be assumed that the calculated and measured precipitation time series are mostly similar and the main 
precipitation events occur in both cases at the same time. PET rates were calculated for the temperature data allocated to the centroids of each catchment. Correlation coefficients of PET calculated based on measured versus MODAWEC temperatures vary from 0.84 to 0.92 for the researched basins.

Figure 7. Time series plots of allocated precipitation to the centroids and measured precipitation at neighboring weather stations of the four river catchments.
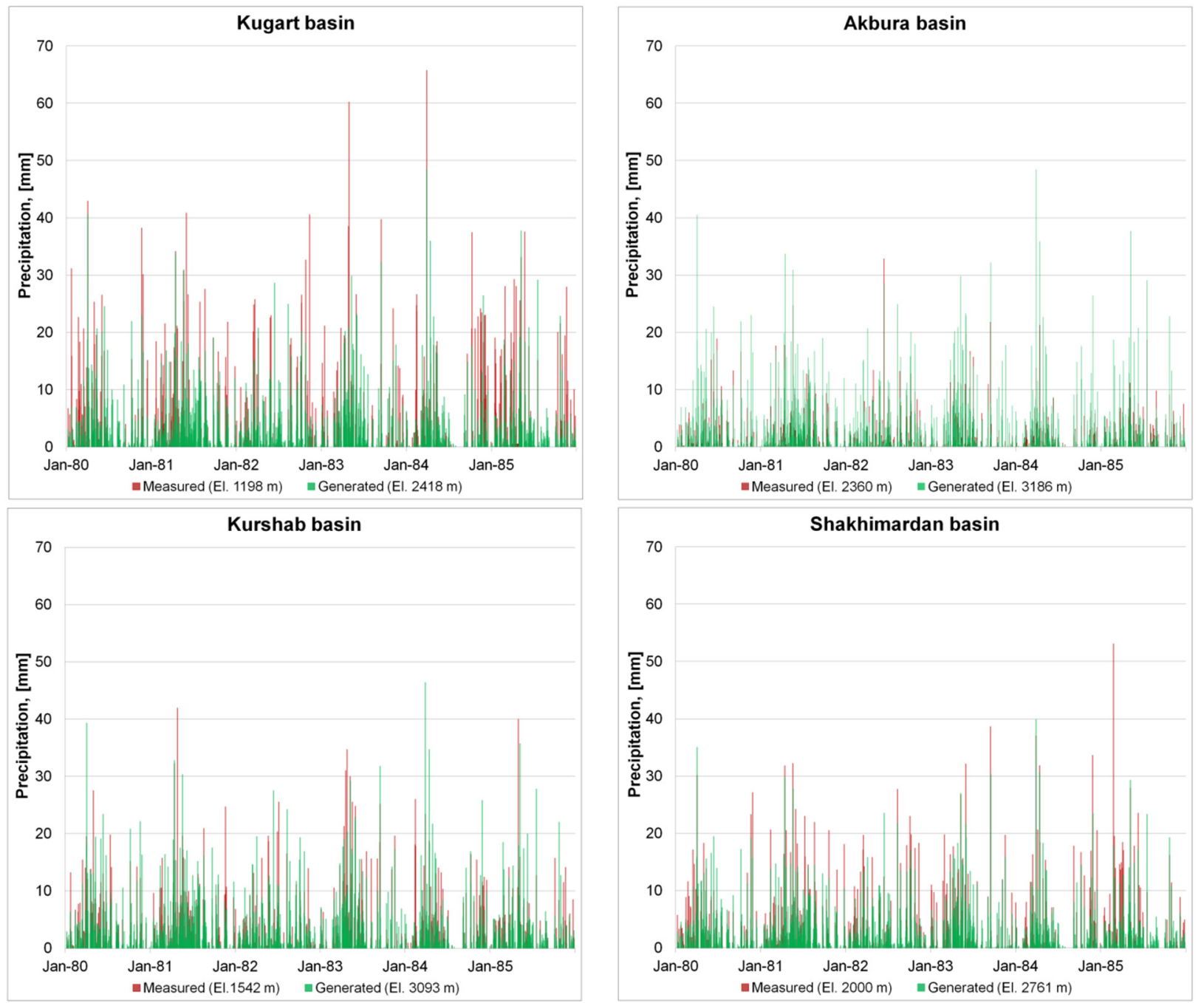

Results of the HBV-light model using both measured as well as MODAWEC input data for the calibration (1980-1983) and validation (1984-1985) period for the four different catchments are presented in Table 4. In general, the HBV-light model is able to replicate the main peaks of discharge $(\mathrm{NSE}=0.50-0.88)$ and simulate the base flow $\left(\mathrm{NSE}_{\log }=0.50-0.85\right)$ in the study area (Figure 8). Higher NSE coefficients were often found for the validation than the calibration period. Similarly, the coefficient of determination $\left(R^{2}\right)$ is higher for the validation $(0.51-0.89)$ than the calibration $(0.50-0.79)$ period. Some extreme discharge peaks are underestimated throughout all catchments, which is mainly attributable to an underestimation of snowmelt in late spring or early summer. From a visual inspection of hydrographs (Figure 8) as well as from the statistical performance criteria (Table 4) we did not find large differences between MODAWEC and measured temperature data-driven HBV-light simulations. Even though in some cases (e.g., Shakhimardan) the NSE dropped slightly, there were other cases where efficiency even 
increased (e.g., NSElog for Akbura). For three of the four catchments the number of overall accepted model runs during calibration period increased when MODAWEC data were used.

Overall, the simulation of hydrological fluxes using HBV-light in combination with MODAWEC input data provided encouraging results, which suggests that using MODAWEC derived data represents a suitable method for water balance assessment in the data-scarce region. The MODAWEC weather generator was also used successfully as pre-processing tool for environmental modeling including the EPIC (Environmental Policy Integrated Climate) model [65]. In the same study, crop yield and evapotranspiration were similar using measured and generated daily meteorological data. Various other studies employed MODAWEC and report acceptable to very good results (NSE $=0.55-0.93$ ) [81-84].

Table 4. Results of calibration and validation of the HBV-light model using allocated measured and generated temperature data, and MLR-calculated precipitation of the four pilot catchments.

\begin{tabular}{|c|c|c|c|c|}
\hline \multirow[t]{2}{*}{ Goodness-of-Fit } & $\begin{array}{c}\text { Calibration, Allocated } \\
\text { Measured Data } \\
\end{array}$ & Validation & $\begin{array}{c}\text { Calibration, Allocated Generated } \\
\text { Temp. Data (MODAWEC) } \\
\end{array}$ & Validation \\
\hline & 1980-1983 & 1984-1985 & $1980-1983$ & 1984-1985 \\
\hline \multicolumn{5}{|c|}{ Kugart river basin } \\
\hline No. Parameter sets & 2556 & 47 & 6973 & 14 \\
\hline NSE & $0.50-0.63$ & $0.50-0.88$ & $0.50-0.61$ & $0.50-0.65$ \\
\hline NSE_log & $0.50-0.71$ & $0.50-0.77$ & $0.50-0.69$ & $0.50-0.67$ \\
\hline$R^{2}$ & $0.50-0.65$ & $0.65-0.89$ & $0.50-0.63$ & $0.54-0.65$ \\
\hline $\begin{array}{l}\text { Cumulative mean } \\
\text { difference, } \mathrm{mm}\end{array}$ & -20 to 20 & -20 to 6 & -20 to 20 & -20 to 8 \\
\hline \multicolumn{5}{|c|}{ Akbura river basin } \\
\hline No. Parameter sets & 79 & 14 & 540 & 12 \\
\hline NSE & $0.50-0.61$ & $0.50-0.68$ & $0.50-0.65$ & $0.50-0.60$ \\
\hline NSE_log & $0.50-0.72$ & $0.50-0.72$ & $0.50-0.77$ & $0.50-0.77$ \\
\hline$R^{2}$ & $0.50-0.67$ & $0.51-0.72$ & $0.50-0.69$ & $0.52-0.61$ \\
\hline $\begin{array}{l}\text { Cumulative mean } \\
\text { difference, } \mathrm{mm}\end{array}$ & -20 to 20 & -20 to 19 & -20 to 20 & 2 to 19 \\
\hline \multicolumn{5}{|c|}{ Kurshab river basin } \\
\hline No. Parameter sets & 55 & 19 & 449 & 18 \\
\hline NSE & $0.50-0.65$ & $0.50-0.65$ & $0.50-0.66$ & $0.50-0.58$ \\
\hline NSE_log & $0.50-0.71$ & $0.50-0.81$ & $0.50-0.71$ & $0.50-0.76$ \\
\hline$R^{2}$ & $0.51-0.68$ & $0.52-0.70$ & $0.50-0.66$ & $0.54-0.69$ \\
\hline $\begin{array}{l}\text { Cumulative mean } \\
\text { difference, } \mathrm{mm}\end{array}$ & -20 to 20 & -17 to 18 & -20 to 20 & -1 to 20 \\
\hline \multicolumn{5}{|c|}{ Shakhimardan river basin } \\
\hline No. Parameter sets & 174 & 66 & 102 & 64 \\
\hline NSE & $0.50-0.70$ & $0.50-0.80$ & $0.50-0.64$ & $0.50-0.80$ \\
\hline NSE_log & $0.50-0.76$ & $0.50-0.85$ & $0.50-0.77$ & $0.50-0.85$ \\
\hline$R^{2}$ & $0.51-0.79$ & $0.52-0.87$ & $0.53-0.73$ & $0.52-0.82$ \\
\hline $\begin{array}{l}\text { Cumulative mean } \\
\text { difference, } \mathrm{mm}\end{array}$ & -20 to 20 & -20 to 19 & -20 to 20 & -17 to 20 \\
\hline
\end{tabular}


Figure 8. Observed (black line) and simulated (grey lines) discharge series for calibration and validation periods (separated by vertical dashed line) using allocated measured (left) and generated (right) temperature and precipitation data for the studied basins.
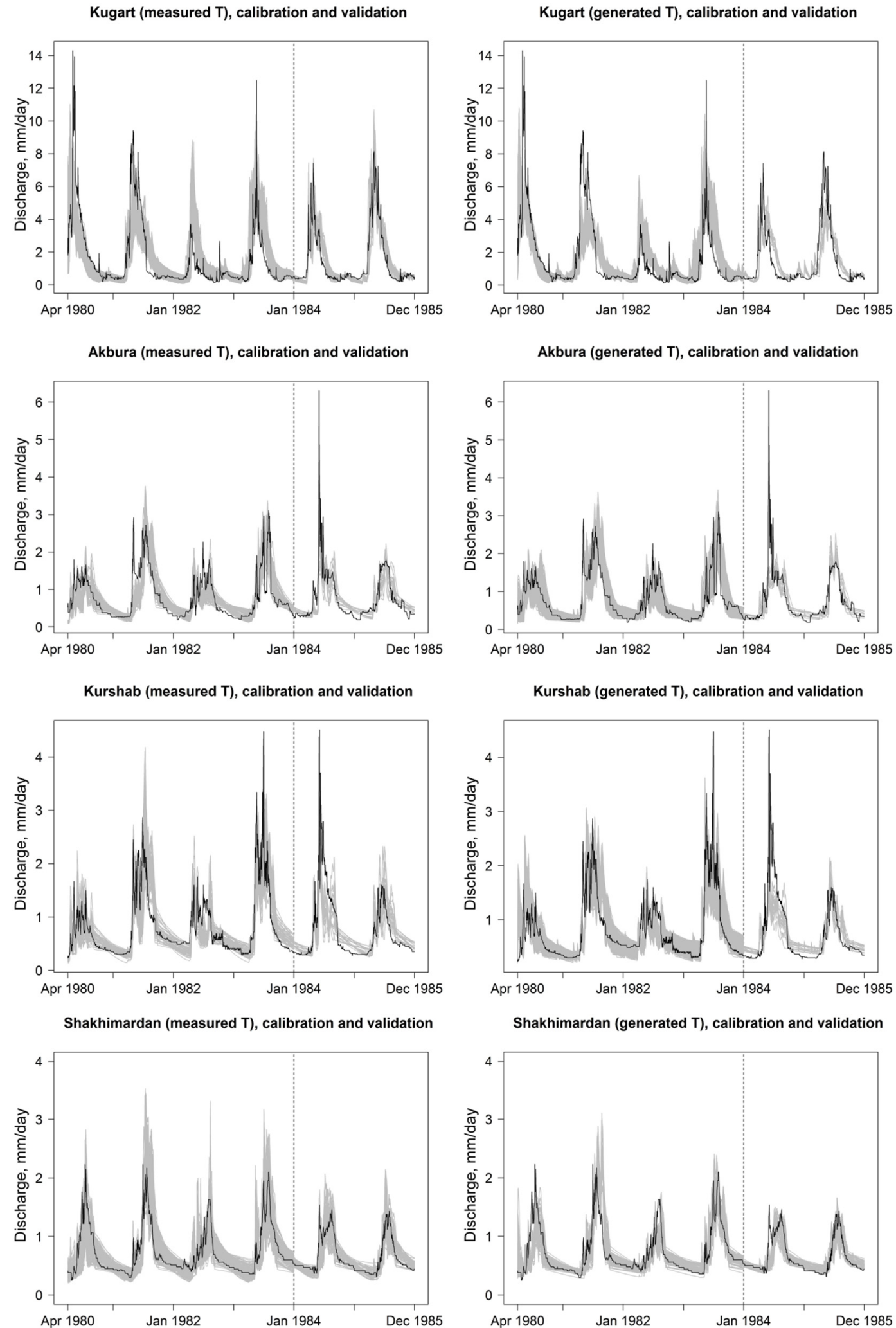

Furthermore, the results show that HBV-light is an acceptable model to be used in the data scarce application of this study. Similar results for HBV-light have been found by others with NSE 
ranging between 0.49 and 0.85 in catchments of Central Asia, China, Central and Northern Europe, and Ethiopia [2,36,39,69,85]. For mountainous catchments in the Himalayan and Central Tibetan Plateau, reported NSE values also vary in comparable ranges of 0.43-0.95 [86] and 0.67-0.82 [33], respectively. Different versions of the HBV models were applied in Central Asia. The HBV-ETH model was used in glacial catchments of Kyrgyzstan [34] and in the Amu-Darya River basin in Tajikistan [87]. Their results showed accurate runoff simulations with NSE coefficients between $0.83-0.89$ and 0.86-0.94, respectively. For the HBV-IWS version applied in Uzbekistan (Chirchik River) NSE ranged between 0.69 and 0.94 [88].

The reasons for differences in model performance are manifold, including divergent model structures (HBV-light versus HBV-ETH and HBV-IWS), varying geographical and meteorological conditions (i.e., a direct comparison of model performance is only valid if different model structures are applied to the same catchment and same boundary conditions), length and split of calibration and validation periods, methods of calibration, and types of efficiency criteria (we used three validation criteria that must be met by the HBV-light model at the same time, while others used single or different combinations of performance criteria).

The majority of the HBV-light model's parameters were calibrated within moderate parameter ranges comparable to other studies [36,38,39] (Tables 5 and 6). The SFCF (Snowfall correction factor) and CFMAX (Degree-day factor) parameters were calibrated within wider ranges. SFCF depends on wind speed and temperature, the greater the wind speed, the greater the SFCF [89,90]. In addition, [91] showed that the gauge catch efficiency ranges between $23 \%$ and $106 \%$ due to gauge type and wind speed. Thus, SFCF can reach large values of 1.5 or greater, which was also shown by others $[36,87,89,92,93]$. CFMAX is low in forested areas [94] and high in glacial regions and zones with high elevation and incoming solar radiation [95]. For example, high values of CFMAX in the Himalayan ranged from 7 to

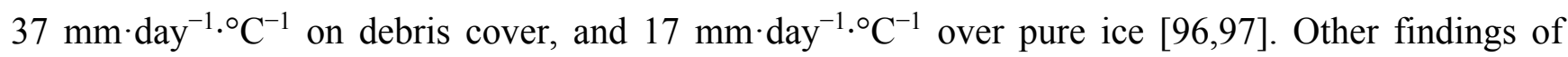
CFMAX were $10 \mathrm{~mm} \cdot \mathrm{day}^{-1 .}{ }^{\circ} \mathrm{C}^{-1}$ in Austria and Switzerland [36] and $14 \mathrm{~mm} \cdot \mathrm{day}^{-1 .}{ }^{\circ} \mathrm{C}^{-1}$ for west China [98]. Reference [95] reviewed a number of studies and reported maxima of up to 20

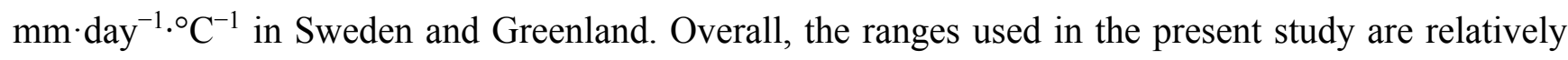
high but still in agreement with other published values.

Table 5. Description of model parameters and their ranges for allocated measured temperature data and calculated precipitation of the four studied catchments.

\begin{tabular}{|c|c|c|c|c|c|c|c|c|c|}
\hline \multirow[t]{2}{*}{ Parameter } & \multirow[t]{2}{*}{ Description/Unit } & \multicolumn{2}{|c|}{$\begin{array}{l}\text { Kugart } \\
\text { River }\end{array}$} & \multicolumn{2}{|c|}{$\begin{array}{c}\text { Akbura } \\
\text { River }\end{array}$} & \multicolumn{2}{|c|}{$\begin{array}{c}\text { Kurshab } \\
\text { River }\end{array}$} & \multicolumn{2}{|c|}{$\begin{array}{c}\text { Shakhimardan } \\
\text { River }\end{array}$} \\
\hline & & Min & Max & Min & Max & Min & Max & Min & Max \\
\hline \multicolumn{10}{|l|}{ Snow Routine } \\
\hline TT & Threshold temperature $/{ }^{\circ} \mathrm{C}$ & -0.5 & 1 & -0.5 & 0.5 & -0.5 & 0.5 & -0.5 & 0.5 \\
\hline CFMAX & $\begin{array}{c}\text { Degree-day } \\
\text { factor } / \mathrm{mm} \cdot{ }^{\circ} \mathrm{C}^{-1} \cdot \mathrm{d}^{-1}\end{array}$ & 2 & 15 & 2 & 15 & 2 & 15 & 1 & 12 \\
\hline SFCF & Snowfall correction factor/- & 0.5 & 3 & 0.1 & 1.5 & 0.1 & 1.5 & 0.3 & 1 \\
\hline CWH & Water holding capacity/- & 0.2 & 0.5 & 0.05 & 0.5 & 0.05 & 0.5 & 0.2 & 0.5 \\
\hline CFR & Refreezing coefficient/- & 0.2 & 0.9 & 0.05 & 0.6 & 0.05 & 0.6 & 0.05 & 0.5 \\
\hline CFGlacier & Glacier correction factor/- & - & - & 0.9 & 1.2 & 0.8 & 1.2 & 0.4 & 1.3 \\
\hline CFSlope & Slope correction factor/- & - & - & 1 & 1.1 & 1 & 1.1 & 0.6 & 1.3 \\
\hline
\end{tabular}


Table 5. Cont.

\begin{tabular}{|c|c|c|c|c|c|c|c|c|c|}
\hline \multirow[t]{2}{*}{ Parameter } & \multirow[t]{2}{*}{ Description/Unit } & \multicolumn{2}{|c|}{$\begin{array}{l}\text { Kugart } \\
\text { River }\end{array}$} & \multicolumn{2}{|c|}{$\begin{array}{c}\text { Akbura } \\
\text { River }\end{array}$} & \multicolumn{2}{|c|}{$\begin{array}{l}\text { Kurshab } \\
\text { River }\end{array}$} & \multicolumn{2}{|c|}{$\begin{array}{c}\text { Shakhimarda } \\
\text { n River }\end{array}$} \\
\hline & & Min & Max & Min & Max & Min & Max & Min & Max \\
\hline \multicolumn{10}{|c|}{$\begin{array}{c}\text { Soil and } \\
\text { evaporation Routine }\end{array}$} \\
\hline FC & Field capacity $/ \mathrm{mm}$ & 50 & 350 & 100 & 350 & 50 & 350 & 250 & 550 \\
\hline LP & $\begin{array}{l}\text { Threshold for reduction } \\
\text { of evaporation/- }\end{array}$ & 0.4 & 1 & 0.4 & 1 & 0.3 & 1 & 0.3 & 1 \\
\hline BETA & Shape coefficient/- & 0.3 & 3 & 1.5 & 2.5 & 1 & 5 & 1.5 & 5 \\
\hline \multicolumn{10}{|c|}{$\begin{array}{l}\text { Ground water and } \\
\text { response routine }\end{array}$} \\
\hline K1 & $\begin{array}{l}\text { Recession coefficient } \\
\text { (upper box) } / \mathrm{d}^{-1}\end{array}$ & 0.001 & 0.03 & 0.01 & 0.04 & 0.01 & 0.04 & 0.02 & 0.1 \\
\hline K2 & $\begin{array}{l}\text { Recession coefficient } \\
\quad(\text { lower box }) / \mathrm{d}^{-1}\end{array}$ & 0.005 & 0.03 & 0.001 & 0.01 & 0.001 & 0.01 & 0.001 & 0.01 \\
\hline PERC & $\begin{array}{l}\text { Maximal flow from } \\
\text { upper to lower } \\
\text { box } / \mathrm{mm} \cdot \mathrm{d}^{-1}\end{array}$ & $>0$ & 4 & 1 & 4.5 & 1 & 4.5 & $>0$ & 4 \\
\hline MAXBAS & $\begin{array}{c}\text { Routing, length of } \\
\text { weighting function/d }\end{array}$ & 1 & 5 & 1 & 5 & 1 & 5 & 1 & 5 \\
\hline
\end{tabular}

Table 6. Parameter ranges for the MODAWEC-generated temperature data allocated to the centroids.

\begin{tabular}{|c|c|c|c|c|c|c|c|c|}
\hline \multirow{2}{*}{ Parameter } & \multicolumn{2}{|c|}{ Kugart River } & \multicolumn{2}{|c|}{ Akbura River } & \multicolumn{2}{|c|}{ Kurshab River } & \multicolumn{2}{|c|}{ Shakhimardan River } \\
\hline & Min & Max & Min & Max & Min & Max & Min & Max \\
\hline \multicolumn{9}{|l|}{ Snow routine } \\
\hline $\mathrm{TT} *$ & -0.5 & 0.5 & -0.5 & 0.5 & -0.5 & 0.5 & -0.5 & 0.5 \\
\hline CFMAX & 2 & 15 & 1 & 15 & 2 & 12 & 1 & 12 \\
\hline SFCF & 1 & 3 & 0.1 & 1.5 & 0.5 & 1.5 & 0.4 & 1.2 \\
\hline $\mathrm{CWH}$ & 0.2 & 0.5 & 0.1 & 0.5 & 0.05 & 0.5 & 0.1 & 0.5 \\
\hline CFR & 0.2 & 0.7 & 0.3 & 0.5 & 0.05 & 0.6 & 0.05 & 0.5 \\
\hline CFGlacier & - & - & 0.9 & 1.2 & 0.9 & 1.2 & 0.5 & 1.4 \\
\hline CFSlope & - & - & 1 & 1.06 & 1 & 1.1 & 0.6 & 1.3 \\
\hline \multicolumn{9}{|c|}{ Soil and evaporation routine } \\
\hline $\mathrm{FC}$ & 150 & 350 & 50 & 350 & 150 & 350 & 250 & 550 \\
\hline LP & 0.5 & 1 & 0.4 & 0.7 & 0.5 & 0.9 & 0.3 & 1 \\
\hline BETA & 0.3 & 2.5 & 3 & 5 & 1.5 & 2.5 & 2 & 7 \\
\hline \multicolumn{9}{|c|}{$\begin{array}{l}\text { Groundwater and } \\
\text { response routine }\end{array}$} \\
\hline K1 & 0.01 & 0.02 & 0.01 & 0.03 & 0.01 & 0.04 & 0.02 & 0.06 \\
\hline $\mathrm{K} 2$ & 0.009 & 0.03 & 0.001 & 0.003 & 0.001 & 0.005 & 0.001 & 0.003 \\
\hline PERC & $>0$ & 4 & 0.5 & 3 & $>0$ & 3 & $>0$ & 2 \\
\hline MAXBAS & 1 & 3 & 1 & 4 & 1 & 5 & 1 & 4 \\
\hline
\end{tabular}

Note: * Parameter's description see in Table 5.

Scatter plots for all parameters and NSE coefficients of the four catchments were drawn using results of the MODAWEC-driven HBV-light application to perform sensitivity analysis, as suggested by $[40,44,99]$. Examples of two parameters for the studied basins are presented in Figure 9. While PERC 
was rather constrained for Kugart and Akbura, it was less clear to find optimal parameter values for PERC in the Kurshab and Shakimardan catchments. MAXBAS on the other hand was not constrained for any of the four catchments. We further tested the importance of model parameters for the model outputs by a regression analysis [40,100], for which results are given in Table 7 . The importance of the predictors indicates the influence of the parameters on the model's efficiency coefficients (NSE, NSElog). The regression technique is used among other studies for evaluation of parameter influence on the results $[44,101,102]$. In addition, [44] noticed that parameter sensitivity analyses contribute to output uncertainty reduction and identifiability of parameters which require additional research. The stepwise

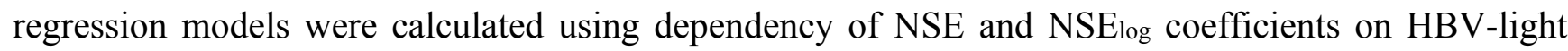
parameters accordingly for different vegetation zones [103], since the snow and soil routine are calculated individually for each vegetation zone [55]. The adjusted coefficients of determination for the

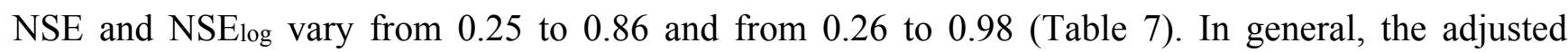
coefficients of determination are higher in validation, which indicates better explanation of the variability in the model's efficiency coefficients because of parameter combination [104]. The total number of parameters in the regression models varies from 2 to 18 (Table 7). The standardized beta coefficients are included in the table only if they are statistically significant ( $p$-value $\leq 0.05)$. The beta values determine how strongly the parameters affect the dependent variable. The higher the beta value the greater the contribution of a parameter to model results [104]. In addition, [105-107] reported that the standardized beta coefficients vary from -1 to 1 and show the decrease or increase in the dependent variable accordingly. Thus, in the studied catchments PERC and K1 have significant influences on the goodnessof-fit coefficients with inverse relationship (0.412-0.936) and positive direction (0.548-0.730) accordingly. In general, the following parameters are relevant for high-flow simulations: PERC, CFMAX, SFCF, CWH, K1, and LP. The most important parameters responsible for recession flows are PERC, CFMAX and TT, followed by K1, Alpha, LP and CWH.

Reference [66] carried out a parameter sensitivity analysis of HBV-light in Sweden and reported that SFCF, MAXBAS, CFMAX and K1 were the most sensitive parameters. [108] applied HBV-light in North-Eastern Germany, and revealed that the most sensitive parameters were SFCF, CFMAX, FC (Field capacity), LP (Limit for potential evaporation), BETA (Shape coefficient), Alpha, K1 and MAXBAS (Length of triangular weighting function). In an Ethiopian case study [85] derived FC, PERC, BETA and $\mathrm{K} 2$ as most sensitive, while K1, MAXBAS, PERC, FC, BETA and LP proved to be relevant for a US catchment [109]. Reference [110] used the HBV-96 model in four different climate zones and found out that the most important parameters for the model are the routing parameter MAXBAS and the recession coefficient KHQ, whereas FC and PERC were insensitive. Obviously, there is not a single most important parameter for HBV applications, but MAXBAS was most often found to be sensitive followed by FC, BETA, K1, as well as LP, SFCF and CFMAX. Surprisingly, MAXBAS was a rather insensitive parameter in our model application. We explain this by the importance of snow and glacial melt that drives the hydrology in the studied catchments.

Finally, we investigated the interaction between the parameters using correlation analysis [111]. Correlations between parameters were analyzed for each catchment with both measured and MODAWEC-generated time series. Instead of many pages of tables, Table 8 summarizes the ranges of all correlation coefficients for each catchment. The linear relationship among parameters was mainly weak. Moderate correlations (0.4-0.6) were mainly found between PERC and K2, Alpha and K1, SFCF 
with CWH (Water holding capacity), BETA, LP, and CFMAX with SFCF, CFGlacier, TT and CFR for the studied catchments. These results indicate a large equifinality of parameters [71] and many unconstrained parameters.

Figure 9. Examples of scatter plots with sensitive (PERC) and insensitive (MAXBAS) parameters for the four studied catchments with MODAWEC generated temperature data.
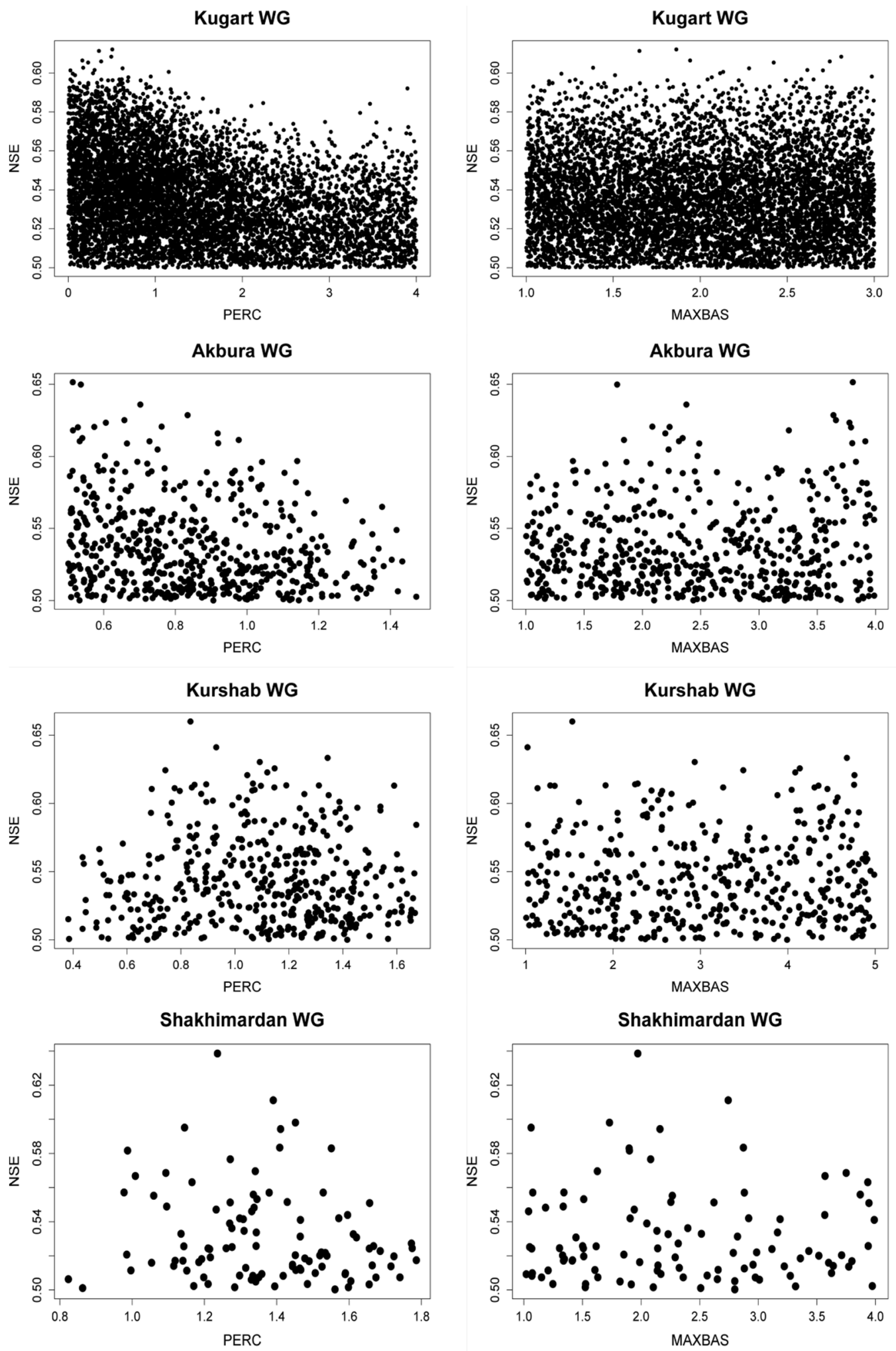
Table 7. Contribution of parameters in HBV-light model for the four studied catchments based on the adjusted coefficient of determination and standardized beta coefficient $(\mathrm{VZ} *=$ vegetation zone).

\begin{tabular}{|c|c|c|c|c|c|c|c|c|c|c|c|c|c|c|c|c|c|}
\hline & \multirow[b]{3}{*}{ Dependent } & \multicolumn{4}{|c|}{ Kugart WG } & \multicolumn{4}{|c|}{ Akbura WG } & \multicolumn{4}{|c|}{ Kurshab WG } & \multicolumn{4}{|c|}{ Shakhimardan WG } \\
\hline & & \multicolumn{2}{|c|}{ Calibration } & \multicolumn{2}{|c|}{ Validation } & \multicolumn{2}{|c|}{ Calibration } & \multicolumn{2}{|c|}{ Validation } & \multicolumn{2}{|c|}{ Calibration } & \multicolumn{2}{|c|}{ Validation } & \multicolumn{2}{|c|}{ Calibration } & \multicolumn{2}{|c|}{ Validation } \\
\hline & & $N S E$ & $N S E_{l o g}$ & $N S E$ & $N S E_{l o g}$ & $N S E$ & $N S E_{\log }$ & $N S E$ & $N S E_{\text {log }}$ & $N S E$ & $N S E_{\text {log }}$ & $N S E$ & $N S E_{\text {log }}$ & $N S E$ & $N S E_{\text {log }}$ & $N S E$ & $N S E_{\log }$ \\
\hline & $R^{2}$ adjusted & 0.25 & 0.38 & 0.75 & 0.52 & 0.28 & 0.77 & 0.86 & 0.98 & $\mathbf{0 . 3 0}$ & 0.44 & 0.64 & 0.95 & 0.29 & 0.26 & 0.76 & 0.86 \\
\hline No & Parameters & \multicolumn{16}{|c|}{ Standardized Beta Coefficient } \\
\hline 1 & PERC & -0.412 & -0.368 & & & -0.201 & -0.826 & & -0.493 & -0.127 & -0.579 & $-\mathbf{0 . 8 5 1}$ & $-\mathbf{0 . 8 8 7}$ & & -0.432 & -0.819 & -0.936 \\
\hline 2 & Alpha & & 0.326 & & & & & -0.453 & -0.382 & & -0.116 & & & & & & \\
\hline 3 & $\mathrm{~K} 1$ & 0.029 & 0.195 & 0.730 & 0.508 & & -0.067 & 0.548 & & -0.183 & -0.258 & & & & & & \\
\hline 4 & $\mathrm{~K} 2$ & 0.166 & 0.027 & & & -0.201 & & & & -0.090 & 0.095 & & & & & & 0.133 \\
\hline 5 & MAXBAS & & -0.019 & & & & & & & & & & & & & & \\
\hline 6 & $\mathrm{TT}_{-} \mathrm{VZ}^{*} 1$ & -0.085 & -0.120 & -0.598 & -0.646 & & & & & -0.088 & & & & & & & \\
\hline 7 & CFMAX_VZ1 & 0.029 & 0.407 & & & & & & & & & & & & & & \\
\hline 8 & SFCF_VZ1 & 0.043 & -0.155 & & & & & & & 0.186 & & & & & & & \\
\hline 9 & CFR_VZ1 & -0.042 & -0.027 & & & & & & -0.134 & 0.116 & 0.089 & & & & & & \\
\hline 10 & CWH_VZ1 & -0.043 & -0.047 & & & & & & & & & & & & & & \\
\hline 11 & CFGlacier_VZ1 & - & - & - & - & & & & & & & -0.515 & & 0.229 & & & \\
\hline 12 & CFSlope_VZ1 & - & - & - & - & & & & & & -0.072 & & & & & & \\
\hline 13 & FC_VZ1 & & -0.026 & & & & & & & -0.095 & & & & & & & \\
\hline 14 & LP_VZ1 & 0.060 & & & & & & & & & & & 0.164 & & -0.258 & -0.193 & -0.132 \\
\hline 15 & BETA_VZ1 & & 0.073 & & & & & & & 0.085 & & -0.381 & & & & & \\
\hline 16 & TT_VZ2 & -0.046 & -0.062 & & & -0.173 & & & & -0.275 & -0.073 & & & & & & \\
\hline 17 & CFMAX_VZ2 & -0.297 & 0.068 & & & 0.162 & -0.103 & -0.403 & -0.549 & 0.353 & & & & & & & \\
\hline 18 & SFCF_VZ2 & 0.231 & 0.116 & & & -0.194 & & & & & & & & & & & \\
\hline 19 & CFR_VZ2 & -0.076 & & & & & & & & & & & & & & & \\
\hline 20 & CWH_VZ2 & 0.036 & & & & -0.174 & & & & -0.357 & -0.135 & & & & & & \\
\hline 21 & CFGlacier_VZ2 & - & - & - & - & & & & & & & & & & & & \\
\hline 22 & CFSlope_VZ2 & - & - & - & - & & & & & & & & & & & & \\
\hline 23 & FC_VZ2 & & -0.062 & & & -0.087 & -0.103 & & & -0.206 & & & & & & & \\
\hline
\end{tabular}


Table 7. Cont.

\begin{tabular}{|c|c|c|c|c|c|c|c|c|c|c|c|c|c|c|c|c|c|}
\hline & \multirow[b]{3}{*}{ Dependent } & \multicolumn{4}{|c|}{ Kugart WG } & \multicolumn{4}{|c|}{ Akbura WG } & \multicolumn{4}{|c|}{ Kurshab WG } & \multicolumn{4}{|c|}{ Shakhimardan WG } \\
\hline & & \multicolumn{2}{|c|}{ Calibration } & \multicolumn{2}{|c|}{ Validation } & \multicolumn{2}{|c|}{ Calibration } & \multicolumn{2}{|c|}{ Validation } & \multirow[b]{2}{*}{$N S E$} & \multirow[b]{2}{*}{$N S E_{\text {log }}$} & \multicolumn{2}{|c|}{ Calibration } & \multicolumn{2}{|c|}{ Validation } & \multicolumn{2}{|c|}{ Calibration } \\
\hline & & $N S E$ & $\begin{array}{c}N S E_{l o} \\
g \\
\end{array}$ & $N S E$ & $N S E_{l o g}$ & $N S E$ & $N S E_{\text {log }}$ & $N S E$ & $N S E_{l o g}$ & & & $N S E$ & $N S E_{\text {log }}$ & $N S E$ & $N S E_{\text {log }}$ & $N S E$ & $N S E_{l o g}$ \\
\hline & $R^{2}$ adjusted & 0.25 & 0.38 & 0.75 & 0.52 & 0.28 & 0.77 & 0.86 & 0.98 & 0.30 & 0.44 & 0.64 & 0.95 & 0.29 & 0.26 & 0.76 & 0.86 \\
\hline No & Parameters & \multicolumn{16}{|c|}{ Standardized Beta Coefficient } \\
\hline 24 & LP_VZ2 & 0.148 & & & & & 0.077 & & & -0.128 & -0.131 & & & & & & \\
\hline 25 & BETA_VZ2 & -0.180 & 0.175 & & & & & & & 0.100 & 0.110 & & & & & & \\
\hline 26 & TT_VZZ3 & - & - & - & - & 0.247 & & & & & & & & & & & \\
\hline 27 & CFMAX_VZ3 & - & - & - & - & -0.400 & & & & -0.258 & -0.079 & & & & & 0.449 & 0.341 \\
\hline 28 & SFCF_VZ3 & - & - & - & - & 0.335 & -0.050 & & & 0.171 & & & -0.129 & 0.293 & & & \\
\hline 29 & CFR_VZ3 & - & - & - & - & & & & & & & & & -0.198 & & & \\
\hline 30 & CWH_VZ3 & - & - & - & - & 0.270 & -0.097 & & & & & & & & & & \\
\hline 31 & CFGlacier_VZ3 & - & - & - & - & & & & & & & & & & & & \\
\hline 32 & CFSlope_VZ3 & - & - & - & - & & & & & & & & & & & & \\
\hline 33 & FC_VZ3 & - & - & - & - & & -0.064 & & & -0.112 & -0.099 & & & & & & \\
\hline 34 & LP_VZ3 & - & - & - & - & & & & 0.166 & -0.096 & -0.092 & & & 0.395 & & & \\
\hline \multirow[t]{2}{*}{35} & BETA_VZ3 & - & - & - & - & & 0.045 & & & & & & & 0.202 & & & \\
\hline & Total & 16 & 17 & 2 & 2 & 11 & 9 & 3 & 5 & 18 & 13 & 3 & 3 & 5 & 2 & 3 & 4 \\
\hline
\end{tabular}


Table 8. The range of correlation coefficients among the parameters generated using the MC method for the studied basins. NA = not available, parameter is only needed for glaciered catchments.

\begin{tabular}{|c|c|c|c|c|c|c|c|c|c|c|c|c|c|c|c|c|}
\hline \multirow{2}{*}{ Parameters } & \multicolumn{2}{|c|}{ Akbura } & \multicolumn{2}{|c|}{ Akbura_WG } & \multicolumn{2}{|c|}{ Kugart } & \multicolumn{2}{|c|}{ Kugart_WG } & \multicolumn{2}{|c|}{ Kurshab } & \multicolumn{2}{|c|}{ Kurshab_WG } & \multicolumn{2}{|c|}{ Shakhimardan } & \multicolumn{2}{|c|}{ Shakhimardan_WG } \\
\hline & $\max$ & $\min$ & $\max$ & $\min$ & $\max$ & $\min$ & $\max$ & Min & $\max$ & $\min$ & $\max$ & $\min$ & $\max$ & $\min$ & $\max$ & $\min$ \\
\hline PERC & 0.4 & -0.2 & 0.4 & -0.1 & 0.3 & -0.1 & 0.4 & -0.1 & 0.3 & -0.2 & 0.3 & -0.1 & 0.3 & -0.1 & 0.4 & -0.3 \\
\hline Alpha & 0.2 & -0.3 & 0.1 & -0.1 & 0.1 & -0.6 & 0.0 & -0.3 & 0.3 & -0.3 & 0.1 & -0.4 & 0.1 & -0.1 & 0.3 & -0.2 \\
\hline $\mathrm{K} 1$ & 0.3 & -0.3 & 0.1 & -0.2 & 0.1 & -0.2 & 0.0 & -0.1 & 0.2 & -0.3 & 0.1 & -0.1 & 0.3 & -0.2 & 0.3 & -0.2 \\
\hline $\mathrm{K} 2$ & 0.2 & -0.3 & 0.1 & -0.3 & 0.2 & -0.3 & 0.1 & 0.0 & 0.2 & -0.3 & 0.1 & -0.3 & 0.3 & -0.3 & 0.1 & -0.3 \\
\hline MAXBAS & 0.2 & -0.2 & 0.1 & -0.1 & 0.0 & 0.0 & 0.0 & 0.0 & 0.3 & -0.3 & 0.1 & -0.1 & 0.2 & -0.2 & 0.2 & -0.1 \\
\hline $\mathrm{TT}$ & 0.3 & -0.3 & 0.1 & 0.0 & 0.0 & -0.1 & 0.0 & 0.0 & 0.3 & -0.3 & 0.1 & -0.1 & 0.2 & -0.2 & 0.2 & -0.2 \\
\hline CFMAX & 0.4 & -0.2 & 0.1 & -0.1 & 0.1 & -0.1 & 0.1 & -0.1 & 0.3 & -0.3 & 0.1 & -0.1 & 0.2 & -0.1 & 0.2 & -0.2 \\
\hline SFCF & 0.2 & -0.3 & 0.1 & -0.1 & 0.1 & -0.6 & 0.3 & -0.3 & 0.5 & -0.6 & 0.1 & -0.2 & 0.2 & -0.3 & 0.4 & -0.1 \\
\hline CFR & 0.2 & -0.1 & 0.1 & -0.1 & 0.0 & -0.1 & 0.0 & 0.0 & 0.2 & -0.4 & 0.1 & -0.1 & 0.2 & -0.1 & 0.2 & -0.1 \\
\hline $\mathrm{CWH}$ & 0.2 & -0.2 & 0.1 & -0.1 & 0.0 & 0.0 & 0.0 & 0.0 & 0.2 & -0.3 & 0.1 & -0.1 & 0.1 & -0.1 & 0.2 & -0.1 \\
\hline CFGlacier & 0.2 & -0.2 & 0.1 & 0.0 & NA & NA & NA & NA & 0.4 & -0.4 & 0.1 & -0.1 & 0.1 & -0.1 & 0.2 & -0.3 \\
\hline CFSlope & 0.2 & -0.3 & 0.1 & -0.1 & NA & NA & NA & NA & 0.4 & -0.2 & 0.1 & -0.1 & 0.1 & -0.1 & 0.1 & -0.1 \\
\hline $\mathrm{FC}$ & 0.2 & -0.2 & 0.1 & -0.1 & 0.0 & 0.0 & 0.0 & 0.0 & 0.2 & -0.2 & 0.1 & -0.1 & 0.1 & -0.2 & 0.2 & -0.1 \\
\hline LP & 0.2 & -0.3 & 0.1 & -0.1 & 0.1 & 0.0 & 0.1 & 0.0 & 0.3 & -0.3 & 0.1 & -0.2 & 0.2 & -0.2 & 0.3 & -0.2 \\
\hline BETA & 0.1 & -0.2 & 0.1 & -0.1 & 0.0 & -0.1 & 0.1 & -0.1 & 0.2 & -0.3 & 0.1 & 0.0 & 0.1 & -0.1 & 0.2 & -0.2 \\
\hline
\end{tabular}




\section{Conclusions}

We have developed a stratified approach to overcome data scarcity and investigate water resource availability for an agricultural hot spot within semi-arid Central Asia. The data scarcity problem associated with shortages in complete temporal coverage and spatial coverage in the studied mountainous area was resolved by inserting a sequence of pre-processing steps including application of lapse rate, simple linear and multiple linear regression methods. In addition, the MODAWEC weather generator was tested for its applicability as a converter of monthly temperature data into daily values for further research in the study area (i.e., catchments with only monthly temperature data). The uncertainty arising from possible errors in hydrometeorological data, gaps filling procedure, parameters identification was reduced using a Monte Carlo simulation approach, the equifinality concept, and a number of goodness-of-fit criteria (NSE, NSElog, mean difference in annual water balance, coefficient of determination) with acceptable thresholds. With respect to the relatively short validation period the results indicated acceptable goodness-of-fit. Therefore, the study suggests that HBV-light in combination with MODAWEC input data proves to be an applicable tool to simulate water resources for the four river catchments in the Ferghana Valley. Accordingly, we aim at applying the developed approach to the remaining catchments in the area in the near future. Future research would profit from more thorough definitions of the ranges of parameters during calibration. This will allow narrowing of behavioral parameter sets and thus improvement of model output.

\section{Acknowledgments}

The first author is grateful to the DAAD for funding this work within the CliNCA (Climate Change Network for Central Asia) project. The meteorological data were received from GeoForschungsZentrum Potsdam (GFZ) within the CAWa (Central Asian Water) project. The runoff data were obtained from Central-Asian Institute of Applied Geosciences (CAIAG), Kyrgyz-Russian Slavic University (Department of Meteorology) and Global Runoff Data Center (GRDC). We like to thank Jean-Francois Exbrayat for initial help during model set-up, Sebastian Multsch for his support in precipitation input dataset generation, and Philip Parker for his support with English editing.

\section{Author Contributions}

Iuliia Radchenko, the first author, carried out the research in the study region and led the manuscript preparation. Lutz Breuer, the second author, contributed many ideas to the research, to the selection of the model, the methodology, and finally to manuscript editing. Irina Forkutsa, supported the preliminary set-up of the HBV-light model and corrected manuscript drafts. Hans-Georg Frede, supervisor of the PhD project, suggested the concept of the project, guided through the analysis of the model's parameters, and corrected manuscript drafts.

\section{Conflicts of Interest}

The authors declare no conflict of interest. 


\section{References}

1. Dukhovny, V.A.; de Schutter, J. Water in Central Asia: Past, Present and Future, 1st ed.; CRC Press: Boca Raton, FL, USA, 2010.

2. Hagg, W.; Braun, L. The Influence of Glacier Retreat on Water Yield from High Mountain Areas: Comparison of Alps and Central Asia. In Climate and Hydrology in Mountain Areas; de Jong, C., Collins, D., Ranzi, R., Eds.; John Wiley \& Sons: Hoboken, NJ, USA, 2006; pp. 261-275.

3. Aizen, V.B.; Aizen, E.M.; Melack, J.M. Climate, snow cover, glaciers, and runoff in the Tien Shan, Central Asia. JAWRA J. Am. Water Resour. Assoc. 1995, 31, 1113-1129.

4. Aizen, V.B.; Kuzmichenok, V.A.; Surazakov, A.B.; Aizen, E.M. Glacier changes in the Tien Shan as determined from topographic and remotely sensed data. Glob. Planet. Chang. 2007, 56, 328-340.

5. Rakhmatullaev, S.; Huneau, F.; le Coustumer, P.; Motelica-Heino, M.; Bakiev, M. Facts and Perspectives of Water Reservoirs in Central Asia: A Special Focus on Uzbekistan. Water 2010, 2 , 307-320.

6. Alam, S.M.; Kidwai, A.H. Regional Imperatives in Utilization and Management of Resources: India and the USSR; Concept Publishing Company: Delhi, India, 1987.

7. Aizen, V.B.; Aizen, E.M.; Melack, J.M.; Dozier, J. Climatic and Hydrologic Changes in the Tien Shan, Central Asia. J. Clim. 1997, 10, 1393-1404.

8. Bolshakov, M.N.; Vyhodcev, I.V.; Nikitina, E.V.; Zabirov, R.D.; Isaev, D.I.; Kashirin, F.T.; Koroev, V.G.; Lunin, B.A.; Mamytov, A.M.; Otorbaev, K.O.; et al. The nature of Kirgizia, Brief Physiographic Description; Kyrgyz State Publishing: Frunze, Kyrghyzstan, 1962. (In Russian)

9. Price, L.W. Mountains and Man: A Study of Process and Environment; University of California Press: Oakland, CA, USA, 1986.

10. Savoskul, O.S.; Chevnina, E.V.; Perziger, F.I.; Vasilina, L.Y.; Baburin, V.L.; AI, A.I.D.; Matyakubov, B.; Murakaev, R.R. Water, Climate, Food, and Environment in the Syr Darya Basin. Available online: http://www.weap21.org/downloads/adaptsyrdarya.pdf (accessed on 17 October 2014).

11. Granit, J.; Jägerskog, A.; Löfgren, R.; Bullock, A.; de Gooijer, G.; Pettigrew, S.; Lindström, A. Regional Water Intelligence Report Central Asia. Available online: http:/www.watergovernance. org/documents/WGF/Reports/Paper-15_RWIR_Aral_Sea.pdf (accessed on 17 October 2014).

12. Parry, M.L.; Canziani, O.F.; Palutikof, J.P.; van der Linden, P.J.; Hanson, C.E. Climate Change 2007: Impacts, Adaptation and Vulnerability; Intergovernmental Panel on Climate Change; Cambridge University Press: Cambridge, UK, 2007; p. 976.

13. Kuzmichenok, V.A. Monitoring of Water, Snow and Glacial Resources of Kyrgyzstan. In Proceedings of the Regional Workshop on Assessment of Snow-Glacier and Water Resources in Asia, Almaty, Kazakhstan, 28-30 November 2006; pp. 28-39.

14. Narama, C.; Kääb, A.; Duishonakunov, M.; Abdrakhmatov, K. Spatial variability of recent glacier area changes in the Tien Shan Mountains, Central Asia, using Corona ( 1970), Landsat ( 2000), and ALOS ( 2007) satellite data. Glob. Planet Chang. 2010, 71, 42-54.

15. Bolch, T. Climate change and glacier retreat in northern Tien Shan (Kazakhstan/Kyrgyzstan) using remote sensing data. Glob. Planet Chang. 2007, 56, 1-12. 
16. Khromova, T.E.; Osipova, G.B.; Tsvetkov, D.G.; Dyurgerov, M.B.; Barry, R.G. Changes in glacier extent in the eastern Pamir, Central Asia, determined from historical data and ASTER imagery. Remote Sens. Environ. 2006, 102, 24-32.

17. Immerzeel, W.W.; Bierkens, M.F.P. Asia's water balance. Nat. Geosci. 2012, 5, 841-842.

18. Bucknall, J. Irrigation in Central Asia: Social, Economic and Environmental Considerations; World Bank, Europe and Central Asia Region, Environmentally and Socially Sustainable Development: Washington, DC, USA, 2003.

19. Sokolov, V.I. Integrated Water Resources Management in the Republic of Uzbekistan. Water Int. 1999, 24, 104-115.

20. State Water Cadastre. Annual Data about the Regime and Resources of Surface Water; Kyrgyz SSR: Obninsk, Russia, 1987; Volume 9. (In Russian)

21. The Global Runoff Data Centre, Germany. Available online: http://www.bafg.de/GRDC (accessed on 18 April 2011).

22. Artem, D. Ferghana valley: Problems of maintaining economic stability. Cent. Asia Cauc. 2007, 2, 113-125.

23. Tateishi, R.; Ahn, C.H. Mapping evapotranspiration and water balance for global land surfaces. ISPRS J. Photogramm. Remote Sens. 1996, 51, 209-215.

24. Jackson, R.B.; Carpenter, S.R.; Dahm, C.N.; McKnight, D.M.; Naiman, R.J.; Postel, S.L.; Running, S.W. Water in a changing world. Ecol. Appl. 2001, 11, 1027-1045.

25. Piper, S.C.; Stewart, E.F. A gridded global data set of daily temperature and precipitation for terrestrial biospheric modeling. Glob. Biogeochem. Cycles 1996, 10, 757-782.

26. Zhang, W.; Li, T.; Huang, Y.; Zhang, Q.; Bian, J.; Han, P. Estimation of uncertainties due to data scarcity in model upscaling: A case study of methane emissions from rice paddies in China. Geosci. Model Dev. Discuss. 2014, 7, 181-216.

27. Bárdossy, A.; Singh, S.K. Robust estimation of hydrological model parameters. Hydrol. Earth Syst. Sci. 2008, 5, 1641-1675.

28. Guerrero, J.-L.; Westerberg, I.K.; Halldin, S.; Lundin, L.-C.; Xu, C.-Y. Exploring the hydrological robustness of model-parameter values with alpha shapes. Water Resour. Res. 2013, 49, 6700-6715.

29. Akhtar, M.; Ahmad, N.; Booij, M.J. The impact of climate change on the water resources of Hindukush-Karakorum-Himalaya region under different glacier coverage scenarios. J. Hydrol. 2008, 355, 148-163.

30. Akhtar, M.; Ahmad, N.; Booij, M.J. Use of regional climate model simulations as input for hydrological models for the Hindukush-Karakorum-Himalaya region. Hydrol. Earth Syst. Sci. 2009, 13, 1075-1089.

31. Chen, H.; Xiang, T.; Zhou, X.; Xu, C.-Y. Impacts of climate change on the Qingjiang Watershed's runoff change trend in China. Stoch. Environ. Res. Risk Assess. 2012, 26, 847-858.

32. Chen, H.; Xu, C.-Y.; Guo, S. Comparison and evaluation of multiple GCMs, statistical downscaling and hydrological models in the study of climate change impacts on runoff. J. Hydrol. 2012, 434, 36-45.

33. Gao, H.; He, X.; Ye, B.; Pu, J. Modeling the runoff and glacier mass balance in a small watershed on the Central Tibetan Plateau, China, from 1955 to 2008. Hydrol. Process. 2012, 26, 1593-1603. 
34. Hagg, W.; Braun, L.N.; Kuhn, M.; Nesgaard, T.I. Modeling of hydrological response to climate change in glacierized Central Asian catchments. J. Hydrol. 2007, 332, 40-53.

35. Kang, E.; Cheng, G.; Lan, Y.; Jin, H. A model for simulating the response of runoff from the mountainous watersheds of inland river basins in the arid area of northwest China to climatic changes. Sci. China Ser. D Earth Sci. 1999, 42, 52-63.

36. Konz, M.; Seibert, J. On the value of glacier mass balances for hydrological model calibration. J. Hydrol. 2010, 385, 238-246.

37. Seibert, J.; Vis, M.J.P. Teaching hydrological modeling with a user-friendly catchment-runoff-model software package. Hydrol. Earth Syst. Sci. 2012, 16, 3315-3325.

38. Uhlenbrook, S.; Seibert, J.; Leibundgut, C.; Rodhe, A. Prediction uncertainty of conceptual rainfall-runoff models caused by problems in identifying model parameters and structure. Hydrol. Sci. J. 1999, 44, 779-797.

39. Steele-Dunne, S.; Lynch, P.; McGrath, R.; Semmler, T.; Wang, S.; Hanafin, J.; Nolan, P. The impacts of climate change on hydrology in Ireland. J. Hydrol. 2008, 356, 28-45.

40. Muleta, M.K.; Nicklow, J.W. Sensitivity and uncertainty analysis coupled with automatic calibration for a distributed watershed model. J. Hydrol. 2005, 306, 127-145.

41. Beven, K.; Binley, A. The future of distributed models: Model calibration and uncertainty prediction. Hydrol. Process. 1992, 6, 279-298.

42. Butts, M.B.; Payne, J.T.; Kristensen, M.; Madsen, H. An evaluation of the impact of model structure on hydrological modeling uncertainty for streamflow simulation. J. Hydrol. 2004, 298, 242-266.

43. Ratto, M.; Young, P.C.; Romanowicz, R.; Pappenberger, F.; Saltelli, A.; Pagano, A. Uncertainty, sensitivity analysis and the role of data based mechanistic modeling in hydrology. Hydrol. Earth Syst. Sci. 2007, 11, 1249-1266.

44. Hamby, D.M. A review of techniques for parameter sensitivity analysis of environmental models. Environ. Monit. Assess. 1994, 32, 135-154.

45. Team, G. GeoNetwork Opensource Portal to Spatial Data and Informatio. Aviliable online: http://www.fao.org/geonetwork/srv/en/metadata.show?id=14116 (accessed on 17 October 2014)

46. Michéli, E.; Schad, P.; Spaargaren, O.; Dent, D.; Nachtergaele, F. World Reference Base for Soil Resources: A Framework for International Classification, Correlation and Communication; FAO (Food and Agriculture Organization): Rome, Italy, 2006.

47. Joseph, G. Fundamentals of Remote Sensing, 2nd ed.; Universities Press: Madison, CT, USA, 2005.

48. УСУБАЛИЕВ, Р.А.; ДУДАШВИЛИ, А.С.; ЭЛЕМАНОВ, О.И. Оледенение северных склонов Туркестанского и Алайского хребтов и его современная динамика. ЛЕД И СНЕГ 2012, 1, 24-28. (Usubaliev, R.A., Dudashvili, A.S., Elemanov, O.I. Glaciation of the northern slopes of Turkestan and Alay Range and its current dynamics). (In Russian)

49. Bacchi, B.; Kottegoda, N.T. Identification and calibration of spatial correlation patterns of rainfall. J. Hydrol. 1995, 165, 311-348.

50. Celleri, R.; Willems, P.; Buytaert, W.; Feyen, J. Spac-time rainfall variability in the Paute basin, Ecuadorian Andes. Hydrol. Process. 2007, 21, 3316-3327. 
51. Makhuvha, T.; Pegram, G.; Sparks, R.; Zucchini, W. Patching rainfall data using regression methods: 1. Best subset selection, EM and pseudo-EM methods: Theory. J. Hydrol. 1997, 198, 289-307.

52. De Gaetano, A.T.; Eggleston, K.L.; Knapp, W.W. A Method to Estimate Missing Daily Maximum and Minimum Temperature Observations. J. Appl. Meteorol. 1995, 34, 371-380.

53. Prieto, L.; Herrera, R.G.; Díaz, J.; Hernández, E.; del Teso, T. Minimum extreme temperatures over Peninsular Spain. Glob. Planet. Chang. 2004, 44, 59-71.

54. Villazón, M.F.; Willems, P. Filling gaps and Daily Disaccumulation of Precipitation Data for Rainfall-runoff model. Water Obs. Inf. Syst. Decis. Support 2010, 2, 1-9.

55. Seibert, J. HBV-Light Version 2 User's Manual. Available online: http://people.su.se/ jseib/ HBV/HBV_light.html (accessed on 17 October 2014).

56. Basist, A.; Bell, G.D.; Meentemeyer, V. Statistical relationships between topography and precipitation patterns. J. Clim. 1994, 7, 1305-1315.

57. Daly, C.; Neilson, R.P.; Phillips, D.L. A statistical-topographic model for mapping climatological precipitation over mountainous terrain. J. Appl. Meteorol. Climatol. 1994, 33, 140-158.

58. Hay, L.; Viger, R.; McCABE, G. Precipitation interpolation in mountainous regions using multiple linear regression. Int. Assoc. Hydrol. Sci. 1998, 248, 33-38.

59. Marquínez, J.; Lastra, J.; García, P. Estimation models for precipitation in mountainous regions: The use of GIS and multivariate analysis. J. Hydrol. 2003, 270, 1-11.

60. Ranhao, S.; Baiping, Z.; Jing, T. A multivariate regression model for predicting precipitation in the Daqing Mountains. Mt. Res. Dev. 2008, 28, 318-325.

61. Hoogenboom, G. Contribution of agrometeorology to the simulation of crop production and its applications. Agric. For. Meteorol. 2000, 103, 137-157.

62. Ivanov, V.Y.; Bras, R.L.; Curtis, D.C. A weather generator for hydrological, ecological, and agricultural applications. Water Resour. Res. 2007, 43, doi:10.1029/2006WR005364.

63. Kou, X.; Ge, J.; Wang, Y.; Zhang, C. Validation of the weather generator CLIGEN with daily precipitation data from the Loess Plateau, China. J. Hydrol. 2007, 347, 347-357.

64. Richardson, C.W. Stochastic simulation of daily precipitation, temperature, and solar radiation. Water Resour. Res. 1981, 17, 182-190.

65. Liu, J.; Williams, J.R.; Wang, X.; Yang, H. Using MODAWEC to generate daily weather data for the EPIC model. Environ. Model. Softw. 2009, 24, 655-664.

66. Harlin, J.; Kung, C.S. Parameter uncertainty and simulation of design floods in Sweden. J. Hydrol. 1992, 137, 209-230.

67. Lindström, G.; Johansson, B.; Persson, M.; Gardelin, M.; Bergström, S. Development and test of the distributed HBV-96 hydrological model. J. Hydrol. 1997, 201, 272-288.

68. Seibert, J. Regionalisation of parameters for a conceptual rainfall-runoff model. Agric. For. Meteorol. 1999, 98, 279-293.

69. Seibert, J.; Uhlenbrook, S.; Leibundgut, C.; Halldin, S. Multiscale calibration and validation of a conceptual rainfall-runoff model. Phys. Chem. Earth Part B Hydrol. Oceans Atmos. 2000, 25, 59-64.

70. Seibert, J. Estimation of parameter uncertainty in the HBV model. Nord. Hydrol. 1997, 28, 247-262. 
71. Allen, R.G.; Pereira, L.S.; Raes, D.; Smith, M. Crop Evapotranspiration-Guidelines for Computing Crop Water Requirements-FAO IRRIGATION and Drainage Paper 56; Food and Agriculture Organization (FAO): Rome, Italy, 1998; Volume 300, p. 6541.

72. Allen, R.G.; Pruitt, W.O.; Wright, J.L.; Howell, T.A.; Ventura, F.; Snyder, R.; Itenfisu, D.; Steduto, P.; Berengena, J.; Yrisarry, J.B.; et al. A recommendation on standardized surface resistance for hourly calculation of reference ETo by the FAO56 Penman-Monteith method. Agric. Water Manag. 2006, 81, 1-22.

73. Smith, M. CROPWAT: A Computer Program for Irrigation Planning and Management; Food and Agriculture Organization: Rome, Italy, 1992.

74. Beven, K.; Freer, J. Equifinality, data assimilation, and uncertainty estimation in mechanistic modeling of complex environmental systems using the GLUE methodology. J. Hydrol. 2001, 249, 11-29.

75. Freer, J.; Beven, K.; Ambroise, B. Bayesian estimation of uncertainty in runoff prediction and the value of data: An application of the GLUE approach. Water Resour. Res. 1996, 32, 2161-2173.

76. Samuel, J.; Coulibaly, P.; Metcalfe, R.A. Identification of rainfall-runoff model for improved baseflow estimation in ungauged basins. Hydrol. Process. 2012, 26, 356-366.

77. Shields, C.A.; Tague, C.L. Assessing the Role of Parameter and Input Uncertainty in Ecohydrologic Modeling: Implications for a Semi-arid and Urbanizing Coastal California Catchment. Ecosystems 2012, 15, 775-791.

78. Viviroli, D.; Archer, D.; Buytaert, W.; Fowler, H.; Greenwood, G.; Hamlet, A.; Huang, Y.; Koboltschnig, G.; Litaor, M.I.; López-Moreno, J.I.; et al. Climate change and mountain water resources: Overview and recommendations for research, management and policy. Hydrol. Earth Syst. Sci. 2011, 15, 471-504.

79. Wöhling, T.; Lennartz, F.; Zappa, M. Technical note: Updating procedure for flood forecasting with conceptual HBV-type models. Hydrol. Earth Syst. Sci. 2006, 10, 783-788.

80. Zappa, M.; Kan, C. Extreme heat and runoff extremes in the Swiss Alps. Nat. Hazards Earth Syst. Sci. 2007, 7, 375-389.

81. Berhane, F.G. Model Based Assessment of Potential Impacts of Climate Change on the Flow of the Main Headwaters of the Nile River: Equatorial Lakes Region and Blue Nile Basins. Master's Theses, University of Connecticut, Storrs, CT, USA, 2011.

82. Khoi, D.N.; Suetsugi, T. Uncertainty in climate change impacts on streamflow in Be River Catchment, Vietnam. Water Environ. J. 2012, 26, 530-539.

83. Mahmood, R.; Babel, M.S. Evaluation of SDSM developed by annual and monthly sub-models for downscaling temperature and precipitation in the Jhelum basin, Pakistan and India. Theor. Appl. Climatol. 2013, 113, 1-18.

84. Xu, Y.-P.; Zhang, X.; Ran, Q.; Tian, Y. Impact of climate change on hydrology of upper reaches of Qiantang River Basin, East China. J. Hydrol. 2013, 483, 51-60.

85. Uhlenbrook, S.; Mohamed, Y.; Gragne, A.S. Analyzing catchment behavior through catchment modeling in the Gilgel Abay, Upper Blue Nile River Basin, Ethiopia. Hydrol. Earth Syst. Sci. 2010, $14,2153-2165$. 
86. Braun, L.N.; Grabs, W.; Rana, B. Application of a conceptual precipitation-runoff model in the Langtang Kfaola Basin, Nepal Himalaya. In Snow and Glacier Hydrology, Proceedings of the Kathmandu Symposium; Young, G.J., Ed.; IAHS (International Association of Hydrological Sciences): Wallingford, UK, 1993; pp. 221-237.

87. Hagg, W.; Hoelzle, M.; Wagner, S.; Mayr, E.; Klose, Z. Glacier and runoff changes in the Rukhk catchment, upper Amu-Darya basin until 2050. Glob. Planet Chang. 2013, 110, 62-73.

88. Gafurov, A. Water Balance Modeling for Meso-Scale Catchments under Data Limited Conditions. Master's Thesis, Institut für Wasserbau, Universität Stuttgart, Stuttgart, Germany, March 2005.

89. Goodison, B.E.; Sevruk, B.; Klemm, S. WMO solid precipitation measurement intercomparison: Objectives, methodology, analysis. Atmos. Depos. 1989, 179, 57-64.

90. Singh, P.; Singh, V.P. Snow and Glacier Hydrology; Springer: Berlin, Germany, 2001.

91. Goodison, B.E. Precipitation data compatibility in north America and the impact on studies of acid deposition. Jacques W. Delleur 1987, 179, 47-55.

92. Braun, L.N.; Renner, C.B. Application of a conceptual runoff model in different physiographic regions of Switzerland. Hydrol. Sci. J. 1992, 37, 217-231.

93. Mayr, E.; Hagg, W.; Mayer, C.; Braun, L. Calibrating a spatially distributed conceptual hydrological model using runoff, annual mass balance and winter mass balance. J. Hydrol. 2013, 478, 40-49.

94. Martinec, J.; Rango, A. Parameter values for snowmelt runoff modeling. J. Hydrol. 1986, 84, 197-219.

95. Hock, R. Temperature index melt modeling in mountain areas. J. Hydrol. 2003, 282, 104-115.

96. Kayastha, R.B.; Takeuchi, Y.; Nakawo, M.; Ageta, Y. Practical Prediction of Ice Melting Beneath Various Thickness of Debris Cover on Khumbu Glacier, Nepal, using a Positive Degree-Day Factor; IAHS (International Association of Hydrological Sciences): Wallingford, UK, 2000; pp. 71-82.

97. Konz, M.; Uhlenbrook, S.; Braun, L.; Shrestha, A.; Demuth, S. Implementation of a process-based catchment model in a poorly gauged, highly glacierized Himalayan headwater. Hydrol. Earth Syst. Sci. 2007, 11, 1323-1339.

98. Matsuda, Y. Positive degree-day factors for ice ablation on four glaciers in the Nepalese Himalayas and Qinghai-Tibetan Plateau. Bull. Glaciol. Res. 2003, 20, 7-14.

99. Saltelli, A.; Andres, T.H.; Homma, T. Sensitivity analysis of model output. Performance of the iterated fractional factorial design method. Comput. Stat. Data Anal. 1995, 20, 387-407.

100. Saltelli, A.; Tarantola, S.; Campolongo, F. Sensitivity Analysis as an Ingredient of Modeling. Stat. Sci. 2000, 15, 377-395.

101. Chao, Y.-C.E.; Zhao, Y.; Kupper, L.L.; Nylander-French, L.A. Quantifying the relative importance of predictors in multiple linear regression analyses for public health studies. J. Occup. Environ. Hyg. 2008, 5, 519-529.

102. Schielzeth, H. Simple means to improve the interpretability of regression coefficients. Methods Ecol. Evol. 2010, 1, 103-113.

103. Jha, M.K. Evaluating hydrologic response of an agricultural watershed for watershed analysis. Water 2011, 3, 604-617.

104. Perry, R.H.; Charlotte, B.; Isabella, M.; Bob, C. SPSS Explained; Routledge: London, UK, 2004. 
105. Cramer, D.; Howitt, D. The SAGE Dictionary of Statistics: A Practical Resource for Students in the Social Sciences; SAGE: London, UK, 2004.

106. Miller, J.D. Biomedical Communications: Purpose, Audience, and Strategies; Academic Press: Waltham, MA, USA, 2001.

107. Nathans, L.L.; Oswald, F.L.; Nimon, K. Interpreting multiple linear regression: A guidebook of variable importance. Pract. Assess. Res. Eval. 2012, 17, 1-19.

108. Ma, M. Correlation Dimension Analysis of Complex Hydrological Systems: What Information Can the Method Provide? Ph.D. Thesis, Freie Universität Berlin, Berlin, Germany, 2013.

109. Abebe, N.A.; Ogden, F.L.; Pradhan, N.R. Sensitivity and uncertainty analysis of the conceptual HBV rainfall-runoff model: Implications for parameter estimation. J. Hydrol. 2010, 389, 301-310.

110. Lidén, R.; Harlin, J. Analysis of conceptual rainfall-runoff modeling performance in different climates. J. Hydrol. 2000, 238, 231-247.

111. Liu, H.-J.; Hsu, N.-S.; Lee, T.H. Simultaneous identification of parameter, initial condition, and boundary condition in groundwater modeling. Hydrol. Process. 2009, 23, 2358-2367.

(C) 2014 by the authors; licensee MDPI, Basel, Switzerland. This article is an open access article distributed under the terms and conditions of the Creative Commons Attribution license (http://creativecommons.org/licenses/by/4.0/). 